\title{
Steam/oxygen gasification system for the production of clean syngas from switchgrass
}

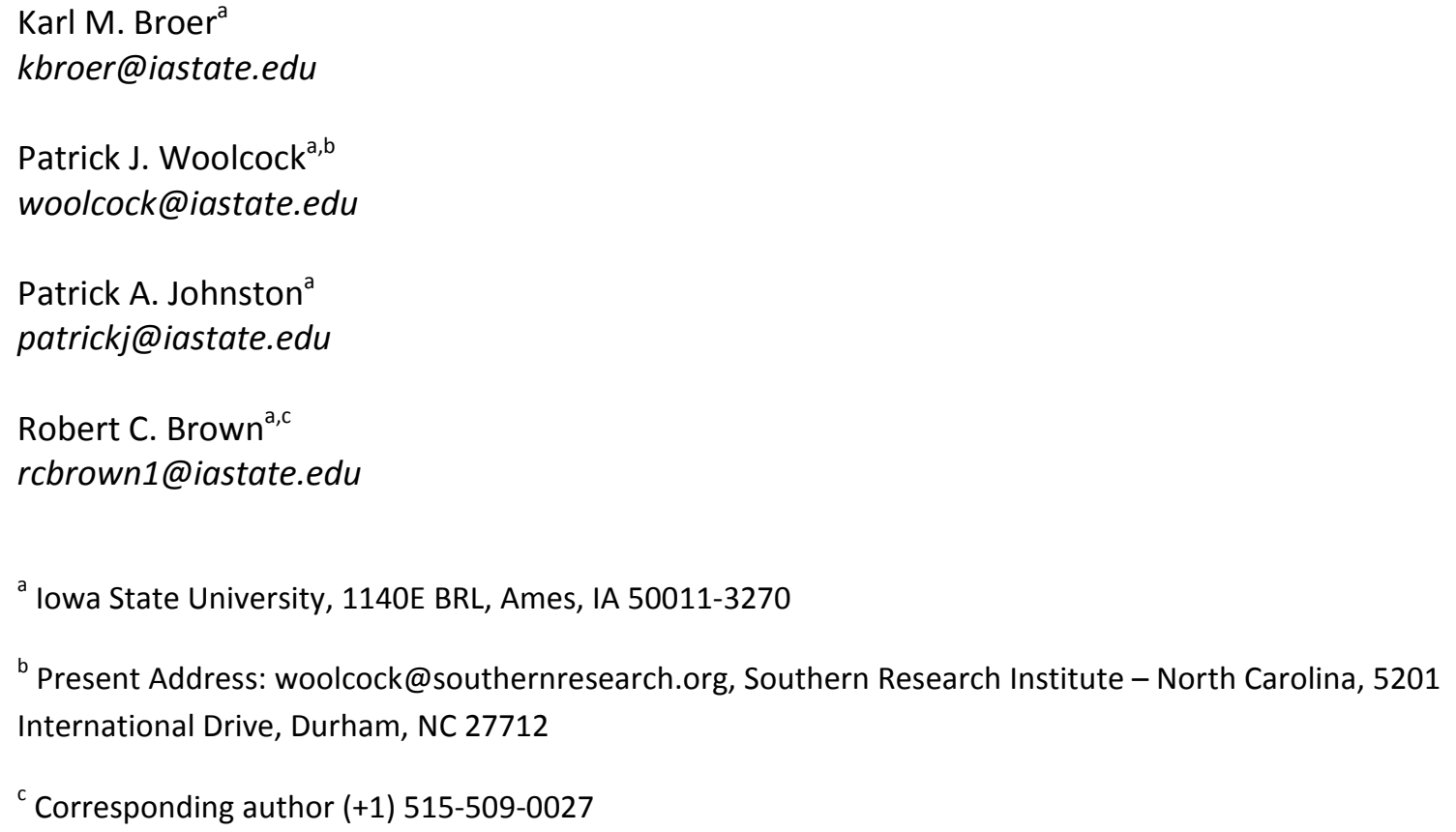

${ }^{\mathrm{C}}$ Corresponding author (+1) 515-509-0027 


\section{Abstract}

A pilot-scale $25 \mathrm{~kg} / \mathrm{h}$ fluidized bed, oxygen/steam blown gasifier and syngas cleaning system was developed to convert switchgrass into clean syngas. The system is rated for operation at gage pressures up to 1 bar. The reactor vessel incorporated a novel guard heating system to simulate near-adiabatic operation of large commercial-scale gasifiers, and was effective for gasification temperatures up to $900^{\circ} \mathrm{C}$. After removing particulate from the gas stream via cyclones, a warm-gas cleaning operation based on oil scrubbing was used to remove tars. Sulfur compounds were removed via solid-phase adsorption. Ammonia was removed by water scrubbing. Baseline gasification tests with steam and oxygen were conducted at equivalence ratios (ER) between 0.21 and 0.38 using switchgrass as fuel. Measurements on the raw and cleaned syngas included permanent gas composition, $\mathrm{C}_{2}$ hydrocarbons, water, heavy and light tars, gasification residues (char and ash), hydrogen sulfide $\left(\mathrm{H}_{2} \mathrm{~S}\right)$, carbonyl sulfide (COS), carbon disulfide $\left(\mathrm{CS}_{2}\right)$, ammonia $\left(\mathrm{NH}_{3}\right)$, and the first reported measurements of hydrogen cyanide (HCN) for oxygen/steam blown gasification. Heavy tars were removed with high efficiency by the method employed, although more difficult to remove light tars reduced overall tar removal efficiency to less than $80 \%$. The sulfur scrubbing system demonstrated $99.9 \%$ removal efficiency, resulting in less than $200 \mathrm{ppb}$ of $\mathrm{H}_{2} \mathrm{~S}$ in the cleaned gas. The $\mathrm{NH}_{3}$ scrubbing system also accomplished greater than $99.9 \%$ removal efficiency, resulting in final $\mathrm{NH}_{3}$ concentrations of less than $1 \mathrm{ppm}$.

\section{Keywords}

Switchgrass; steam/oxygen gasification; fluidized bed; ammonia measurement; hydrogen cyanide measurement; syngas cleanup 


\section{Introduction}

Biomass gasification can convert a wide range of biomass feedstocks into syngas for the production of process heat, electricity, fuels, or chemicals that would otherwise be derived from fossil fuels [1]. Though the term "syngas" was originally defined as a mixture strictly limited to hydrogen gas $\left(\mathrm{H}_{2}\right)$ and carbon monoxide (CO) [2], it has been more widely applied to refer to the gaseous product of any kind of gasification process. We will we use the term syngas here in this broader meaning. Most biomass gasifiers are air-blown and produce syngas that contains roughly $50 \%$ nitrogen gas $\left(\mathrm{N}_{2}\right)$ [2]. This high inert gas content means that the syngas also has relatively low energy content (a higher heating value (HHV) of around $5.5 \mathrm{MJ} / \mathrm{N}-\mathrm{m}^{3}$ [3], compared to $38 \mathrm{MJ} / \mathrm{N}-\mathrm{m}^{3}$ [4] for natural gas). The $\mathrm{N}_{2}$ diluent also makes downstream syngas cleanup and utilization more costly as the equipment must be sized to handle greater volumes of gas. These shortcomings can be remedied by using pure oxygen, oxygenenriched air, or oxygen/steam mixtures as gasification agents. These strategies produce syngas with far less inert gas content and much higher energy content per unit volume. Steam is frequently used because it promotes $\mathrm{H}_{2}$ production via the water-gas shift reaction, and can help control temperature in the gasifier [3].

Steam and oxygen blown gasification studies are relatively rare due to the extra equipment and operational complexity that is required compared to air gasification. Gasification studies employing steam and oxygen-enriched air, which tend to have operating characteristics lying between air gasification and steam and oxygen gasification, are more common. Examples of both types of studies are listed in Table 1. Among the few studies that have been conducted, experimental work related to varying reactor temperature, ratios between the constituents of the fluidizing gas, feedstock type, and bed material has been conducted. While all studies have measured the permanent gas composition of the syngas, data related to char, tar, and water content, sulfur species, and especially nitrogen compounds are sparser.

***Table 1 Citations Placeholder $[5,6,7,8,9,10,11,12]^{* * *}$

In order to study steam/oxygen blown gasification relevant to bioenergy applications, a $25 \mathrm{~kg} / \mathrm{h}$ gasification reactor and downstream syngas cleaning equipment was constructed at lowa State University. The effect of equivalence ratio (ER) on syngas composition and quality was determined, and the performance of a new syngas cleanup system was tested. Many constituents of the syngas were measured including permanent gas, $\mathrm{C}_{2}$ hydrocarbons, water, heavy tar, light tar, char, hydrogen sulfide $\left(\mathrm{H}_{2} \mathrm{~S}\right)$, carbonyl sulfide (COS), carbon disulfide $\left(\mathrm{CS}_{2}\right)$, ammonia $\left(\mathrm{NH}_{3}\right)$, and hydrogen cyanide $(\mathrm{HCN})$.

A novel gas cleaning system was designed to remove char, tar, sulfur, and $\mathrm{NH}_{3}$. After using cyclonic separation to remove most particulate from the syngas, the following unit operations were employed:

1. An oil scrubber for tar and residual particulate removal

2. A packed-bed adsorption system for sulfur removal

3. A water-based absorption scrubber for $\mathrm{NH}_{3}$ removal 


\section{Materials and Methods}

\subsection{Preparation and analysis of biomass}

Switchgrass was harvested by Chariton Valley RC\&D, Inc. near Centerville, lowa, USA and baled into 1.8 $m$ diameter round bales. After transport to lowa State University, the bales were disintegrated and coarsely chopped using a Vermeer BP-8000 whole bale grinder. The material was dried using an Advanced Trailer \& Equipment trailer style drier and then ground again using an Art's Way hammer mill equipped with a $6.35 \mathrm{~mm}(0.25 \mathrm{in})$ screen.

Moisture content was determined by drying the biomass for 72 hours at $95^{\circ} \mathrm{C}$ in a Fisher Scientific IsoTemp Oven. Proximate analysis was conducted using a Mettler Toledo TGA/DSC 1 ThermoGravimetric Analyzer, and determined volatile content, fixed carbon, and ash content. Analysis of carbon, hydrogen, and nitrogen content was conducted using an Elementar vario MICRO cube analyzer. Analysis for ten different ash elements was conducted by using an X-ray fluorescence (XRF) spectrophotometer (PHILIPS PW2404) equipped with a rhodium target X-ray tube and a $4 \mathrm{~kW}$ generator. Oxygen content was found by difference. The combined results of these four analyses are found in Table 2.

\subsection{Feed system}

The gasification reactor was equipped with a custom lock hopper feed system to allow feeding of solid biomass into the pressurized gasification reactor. The feed system was constructed from carbon steel pipe with an inner diameter of $390 \mathrm{~mm}$. It was designed to handle fibrous and low-density particles up to $6 \mathrm{~mm}$ in size. Two knife gate valves were used to admit biomass into the pressurized environment. Nitrogen gas $\left(\mathrm{N}_{2}\right)$ was used to pressurize and blanket the batches of biomass entering the hopper. Biomass was fed into the reactor at $10.3-12.6 \mathrm{~kg} / \mathrm{h}$ via a two-stage auger feeding system consisting of a slow moving variable speed metering auger followed by a faster moving constant speed injection auger for stoking the fluidized bed. A small amount of $\mathrm{N}_{2}$ (10 SLPM) was introduced into the metering auger to cool the auger housing and blanket the biomass with inert gas.

\subsection{Gasifier}

An illustration and a photograph of the gasifier and feed system are shown in Figure 1 and Figure 2, respectively. The gasifier was specially designed to allow pressurized gasification under essentially adiabatic conditions between 650 and $900^{\circ} \mathrm{C}$. The pressure vessel was constructed from $489 \mathrm{~mm}$ I.D. carbon steel pipe of $3050 \mathrm{~mm}$ length. As shown in Figure 3, the pipe was lined with $19 \mathrm{~mm}$ of BTUBLOCK microporous insulation followed by $137 \mathrm{~mm}$ of castable Resco EZ-cubed LO-ERODE refractory, resulting in an internal diameter of $178 \mathrm{~mm}$. Each layer served a distinct purpose. The microporous 
insulation kept the steel pipe from exceeding permissible temperature limits for pressure vessels, and minimized heat loss from the reactor. The castable refractory served as an erosion barrier against the scouring action of fluidized sand in the reactor, and supported six electric cartridge heaters near the perimeter of the fluidized bed. The guard heaters were equipped with integral thermocouples and controlled automatically to maintain the temperature of the refractory slightly above the gasification temperature. This ensured that heat loss from the gasifying biomass was close to zero. Each cartridge heater had a maximum output of $4 \mathrm{~kW}$, for a total of $24 \mathrm{~kW}$ of heating capacity. Two dimensional heat transfer simulations of the reactor cross section indicated that maintaining the thermocouples inside the cartridge heaters at $100^{\circ} \mathrm{C}$ above the gasification temperature would achieve essentially adiabatic gasification. After warm-up of the gasifier, about $8 \mathrm{~kW}$ of power was needed to satisfy temperature requirements while steady-state operation was underway. This was consistent with the approximate heat loss rate predicted by the heat transfer simulation. The temperature profile of the fluidized bed itself was monitored via five evenly spaced thermocouple probes protruding into the center of the reactor.

Upon exiting the reactor, syngas was passed through two gas cyclones in series that were designed according to Stairmand High Efficiency geometry [13]. An automatically actuated valve was used to control gasifier operating pressure by throttling syngas flow, and was located after the cyclones to mitigate char erosion of valve internals. The reactor, feed system, cyclones, and cyclone catches were all designed to be operated at pressures up to 1 bar gauge.

\subsection{Syngas cleanup system}

Three unit operations for cleaning the syngas of fine particulate, tar, sulfur species, and $\mathrm{NH}_{3}$ were carried out downstream of the pressure control valve, and are illustrated in Figure 4. A photograph is included in Figure 5.

Scrubbing of tar and fine particulate was conducted using Xceltherm 600 oil in a $150 \mathrm{~mm}$ I.D. and 2000 $\mathrm{mm}$ tall pressure vessel. Spray nozzles were strategically oriented in the column for effective removal of tar via condensation and aerosol collection [14]. A full cone spray pattern nozzle was located in the middle of the column, and pointed downwards to distribute $200 \mathrm{~kg} / \mathrm{h}$ of recirculated oil to continuously wet a bed of structured packing $1000 \mathrm{~mm}$ tall. This lower half of the scrubber served as the primary heat exchange portion of the column, designed to reduce the incoming gas temperature by $150-250^{\circ} \mathrm{C}$, depending on the inlet temperature. Additional spray streams were then used for the purpose of removing condensed tar aerosols via impingement. A $100 \mathrm{~kg} / \mathrm{h}$ stream of recirculated oil was sprayed in immediately above the middle of the column, and divided between three hollow cone spray nozzles pointed in an upwards swirl pattern. A photograph of this configuration was documented previously by Woolcock [14]. A third and final $20 \mathrm{~kg} / \mathrm{h}$ stream of fresh makeup oil was sprayed straight downwards in a hollow cone pattern near the top of the scrubber. The final $300-450 \mathrm{~mm}$ of column space above the fine misting nozzle served as a disengagement zone, and included a $200 \mathrm{~mm}$ tall mist eliminator at the very top. The temperature of the tar scrubber was maintained above the dew point of the syngas 
(generally between 85 and $100^{\circ} \mathrm{C}$ ) to prevent water condensation, avoiding a two-phase spent oil stream that would have been difficult to treat. To study tar scrubbing performance, syngas tar concentration and makeup was measured both upstream and downstream of the oil scrubber at sampling ports $A$ and $B$ (shown in Figure 4).

The oil scrubber column system included a filtration system and recycle unit to minimize the amount of oil required. A decanting vessel located immediately below the scrubbing tower provided the oil approximately 45 minutes of residence time to allow char and agglomerated tar to settle out of the oil. These compounds were periodically discharged to a holding tank located below the vessel. Fresh oil entering the column at the upper misting nozzle served as makeup oil. All oil streams on the scrubbing system were equipped with Coriolis mass flow meters, and the waste oil tank was mounted on a scale to enable calculation of mass balances.

After the oil scrubber, the syngas was reheated to approximately $400^{\circ} \mathrm{C}$ using a $7.5 \mathrm{~kW}$ Chromalox circulation heater, which was necessary for efficient operation of the sulfur sorbent system. Hydrogen sulfide $\left(\mathrm{H}_{2} \mathrm{~S}\right)$ was removed via solid phase adsorption using two parallel packed bed reactors configured in a lead-lag fashion, with the inactive reactor undergoing regeneration or reloading while the other was in service. Typical operational time was 4-12 h per scrubber vessel, depending on the sulfur concentration in the raw syngas (several hundred to nearly one thousand $p p m \mathrm{H}_{2} \mathrm{~S}$ ). Performance of the sulfur scrubbers was monitored via gas sampling at ports B and C in Figure 4.

Commercially available zinc-oxide based sorbents Actisorb S2 and S6 (Süd-Chemie, Munich, Germany) were utilized as scrubbing media. The $130 \mathrm{~mm}$ diameter and $1220 \mathrm{~mm}$ long reactors were maintained at $400^{\circ} \mathrm{C}$ via automatically controlled Watlow ceramic electrical heaters. Three sets of separately controlled heaters were used for each packed bed. The temperature gradients across the packed beds and their inlet and outlet concentrations of $\mathrm{H}_{2} \mathrm{~S}$ (at gas sampling ports $\mathrm{B}$ and $\mathrm{C}$ in Figure 4) were monitored to determine breakthrough of the adsorption front, upon which the columns were switched.

Saturated sulfur sorbent canisters were either allowed to cool for removal and reloading with fresh sorbent, or were regenerated in place using small amounts of air mixed with nitrogen. Regeneration required special care due to the highly exothermic oxidation reaction that transformed the sulfided metal sorbents back into their oxidized forms. Regeneration air was diluted with nitrogen in order to reduce the concentration of oxygen to a few percent of the gas flow, and temperatures were monitored constantly to avoid any dangerous temperature excursions.

Ammonia and other water-soluble contaminants were removed from the syngas via a water scrubber, the third unit operation of the cleanup system. The scrubbing column was $150 \mathrm{~mm}$ in diameter and 2000 $\mathrm{mm}$ tall. At the top of the column $115 \mathrm{~kg} / \mathrm{h}$ of water was sprayed onto a $1750 \mathrm{~mm}$ tall bed of random packing material consisting of 5/8 inch size stainless steel Pall Rings. The bottom of the column contained level sensors and a discharge drain to maintain a small pool of water at the bottom of the column. Syngas flow proceeded from bottom to top of the scrubber, counter to the flow of water. Syngas exiting the scrubber was $50-60^{\circ} \mathrm{C}$. Performance of the water scrubber was monitored via gas sampling ports $C$ and $D$ in Figure 4. 


\subsection{Gasifier operating conditions}

The fluidized bed material consisted of $12.8 \mathrm{~kg}$ of $40 / 70$ silica sand obtained from Badger Mining Corporation (409 South Church St., Berlin, WI U.S.A.) blended with $3.2 \mathrm{~kg}$ of Uni-Cal 'L' crushed limestone from ILC Resources (3301 106th Circle, Urbandale, IA). The limestone was included in order to absorb the low melting point alkali metals commonly found in herbaceous feedstocks, as discussed by Turn et al. [15] and Basu [16]. The bed was refreshed before each experiment.

For all tests the composition of the fluidizing agent was $50 \mathrm{wt} \%$ oxygen and $50 \mathrm{wt} \%$ steam. Equivalence ratio (ER) was varied from 0.21 to 0.38 by simultaneously adjusting the rates of fluidizing agent and biomass feed into the reactor. The order in which different ER levels were tested was randomized. The reactor was operated at 0.28 bar gauge pressure for all gasification runs. The total mass throughput (biomass, steam, and oxygen) was held constant throughout all tests at $18.3 \mathrm{~kg} / \mathrm{h}$. Despite the constant mass flow, gas residence time of the reactor varied from 4.2-5.6 s between tests due to changes in syngas yield, composition, and temperature. The bed fluidization velocity, assuming that the volatiles released from the biomass during gasification did not contribute toward the fluidization, was between 2.4-3.4 times the minimum fluidization velocity. The minimum fluidization velocity was determined by conducting fluidization tests using air and the electrically pre-heated bed, prior to introduction of feedstock.

\subsection{Gas sampling}

After achieving steady state gasification conditions, gas sampling was conducted for 70-180 minutes. Exact length of data collection time depended on the combined quantity of nitrogen and tar measurements taken. Upon conclusion of data collection, the reactor was shut down. Sampling of raw syngas prior to gas cleaning was conducted by extracting a 1-2 SLPM slipstream via isokinetic sampling at gas sampling port A (Figure 4 ) where syngas temperature was typically $450^{\circ} \mathrm{C}$. A detailed illustration of the sampling line setup is shown in Figure 6. An L-shaped probe was used to extract the slipstream from the main syngas pipeline. The appropriate isokinetic sampling rate was determined beforehand based on the syngas pipeline diameter, the sampling probe diameter, and an approximation of the syngas yield for each set of operating conditions tested. There were over twenty pipe diameters of straight syngas pipeline upstream, and eight pipe diameters downstream of the isokinetic probe to insure established flow conditions. Immediately following extraction, the slipstream was drawn through a $25 \times 90 \mathrm{~mm}$ ceramic thimble filter canister held at $450^{\circ} \mathrm{C}$ to trap particulate for gravimetric measurement. The gas was then passed through a dry tar condenser fabricated from a household pressure cooker in a similar manner to the apparatus utilized by Xu et al. [17]. The dry tar condenser was held at temperatures between 100 and $115^{\circ} \mathrm{C}$. For the purposes of this paper, the tars collected and measured in this manner will be referred to as "heavy tars." For three select tests, measurements of light tars in the raw syngas were also made immediately downstream of the dry tar condenser via a 
novel Solid Phase Micro-Extraction (SPME) technique (Figure 6). The details of the SPME technique are described elsewhere $[14,18]$.

After measurement of tars, the slipstream was bubbled through a pair of $500 \mathrm{~mL}$ glass impingers configured in series. Each impinger was filled with $200 \mathrm{~mL}$ of collection solution for measuring nitrogen species. Two pairs of impingers were used during each experimental run. The first pair was installed for 30 minutes of collection time after which they were removed and replaced with a second pair for a second 30 minute collection time. One pair of impingers was filled with $5 \%$ hydrochloric acid for measuring $\mathrm{NH}_{3}$. The other pair was filled with $100 \mathrm{mM}$ sodium hydroxide for measuring $\mathrm{HCN}$. The order in which the two nitrogen species were collected during each test run was randomized. All impingers were weighed before and after they were used to measure water condensed from the syngas. After collection, the solution from each impinger was transferred into a high quality HDPE sample bottle with a tightly fitting lid. Samples were held at $5^{\circ} \mathrm{C}$ until analysis.

After the impingers, the slipstream was passed through a desiccate canister to remove any remaining moisture. The stream was then analyzed with a Varian CP-4900 micro gas chromatograph $(\mathrm{mGC})$ to measure $\mathrm{N}_{2}, \mathrm{CO}, \mathrm{H}_{2}$, carbon dioxide $\left(\mathrm{CO}_{2}\right)$, methane $\left(\mathrm{CH}_{4}\right)$, ethane $\left(\mathrm{C}_{2} \mathrm{H}_{6}\right)$, ethylene $\left(\mathrm{C}_{2} \mathrm{H}_{4}\right)$, acetylene $\left(\mathrm{C}_{2} \mathrm{H}_{2}\right)$, and helium $(\mathrm{He})$. The flow rate of the sampling line was controlled via a rotameter/valve combination. The total volume of dry syngas sampled was measured using a drum-type total flow gas meter at the end of the sampling line. While gasification was underway, a small He tracer of a known flow rate was injected into the main syngas pipeline just upstream of the gas cyclones. The concentration of $\mathrm{He}$ in the syngas measured by the $\mathrm{mGC}$ could then be used to determine the total volumetric flow rate of syngas.

An Agilent 7890 gas chromatograph (GC) (Santa Clara, CA) with Chemstation version B.04.03 software was use to evaluate the performance of the gas cleanup system. The GC was configured with a WassonECE Instrumentation (Fort Collins, $\mathrm{CO}$ ) custom online gas sampling system, which was connected to sampling ports $B, C$, and $D$ (see Figure 4) via sampling lines that were heat traced and maintained at $250^{\circ} \mathrm{C}$. The GC was equipped with five different detectors for online analysis. An Agilent 355 Sulfur Chemiluminescence Detector ( $S C D$ ) was used to determine $\mathrm{H}_{2} \mathrm{~S}, \mathrm{COS}$, and $\mathrm{C}_{2} \mathrm{~S}$. An Agilent 255 Nitrogen Chemiluminescence Detector (NCD) was used to quantify $\mathrm{NH}_{3}$ concentrations. Two Agilent Thermal Conductivity Detectors (TCD) were used to quantify light hydrocarbons and $\mathrm{NH}_{3}$ at high concentrations (>1000 ppm). The use of three sampling locations and the broad capabilities of this GC system enabled gas composition before and after each gas cleaning stage to be monitored during experiments.

\subsection{Analysis of $\mathrm{NH}_{3}$ and $\mathrm{HCN}$}

The solutions from the acidic impingers, containing $\mathrm{NH}_{3}$ as ammonium ion $\left(\mathrm{NH}_{4}{ }^{+}\right)$, were vacuum filtered through $110 \mathrm{~mm}$ diameter Whatman 42 filter paper and diluted to $500 \mathrm{~mL}$ using deionized water. They were then placed into new plastic sample bottles with tight fitting lids, and transported to MVTL 
Laboratories, Inc. (Nevada, IA) and analyzed for $\mathrm{NH}_{4}^{+}$content via distillation followed by titration in accordance with National Environmental Methods Index Standard Method 4500- $\mathrm{NH}_{3} \mathrm{~B}, \mathrm{C}$ [19].

The samples from the basic impingers were diluted to $500 \mathrm{~mL}$ using $100 \mathrm{mM}$ sodium hydroxide $(\mathrm{NaOH})$. The samples were then agitated, filtered using $0.45 \mu \mathrm{m}$ glass micro-fiber syringe tip filters, and then dispensed into $1500 \mu \mathrm{L}$ sample vials for cyanide ion analysis using a Dionex ICS-3000 ion chromatograph (IC). Samples were brought into detection range of the IC by conducting dilutions with $100 \mathrm{mM} \mathrm{NaOH}$ as needed. Dilutions were conducted with Eppendorf Multipipette Repeaters equipped with tip sizes carefully chosen to maximize precision. All reagents used for aqueous sample operations were prepared using 18.2 $\mathrm{M} \Omega$ deionized water.

\subsection{Equilibrium modeling}

Thermodynamic equilibrium calculations were conducted using the Aspen Plus software package with the inputs being based on the gasification conditions explored in this study. A constant temperature and pressure assumption was employed. Temperatures were specified according to those observed during experimental test runs. Pressure was specified at 0.28 bar for all equilibria calculated. Biomass, steam, and oxygen inputs were also matched to the experimental conditions tested. Nitrogen purge and He tracer gases were omitted from the calculations. The composition of the biomass was simplified to include only the carbon, oxygen, hydrogen, and nitrogen content.

\section{Results}

\subsection{Gasifier performance}

Eight test runs were conducted in order to evaluate gasifier performance. Each test run yielded one measurement of char, heavy tar, water, $\mathrm{NH}_{3}$, and $\mathrm{HCN}$. Between 10 and 30 sets of permanent gas data were collected for each test run, depending on data collection time available. The permanent gas data reported represent the average of these measurements. Due to assorted technical difficulties, one tar, one $\mathrm{HCN}$, and one $\mathrm{NH}_{3}$ data point were not recovered.

Gasification temperature increased almost linearly with equivalence ratio (ER) up to ER of 0.32 (see Figure 7), as would be expected for adiabatic gasification [20]. Padban [21] found a similar linear relationship for an air blown reactor of similar throughput. For operation above $E R=0.32$, the temperature became constant at about $900^{\circ} \mathrm{C}$. This occurred because the operating limits of the cartridge heaters imbedded in the refractory wall had been reached. For process temperatures above $880^{\circ} \mathrm{C}$, it was no longer possible to trim the set point of the cartridge heaters to $100^{\circ} \mathrm{C}$ above the process 
temperature as their operating limit was $980^{\circ} \mathrm{C}$. This resulted in increased heat loss to the surroundings, departing from the near-adiabatic conditions that were otherwise achieved.

Bed agglomeration was another limit to operating above $900^{\circ} \mathrm{C}$. Agglomeration occurred at this temperature after only four hours of fuel feed (representing only 30 minutes of steady state operation). This $900^{\circ} \mathrm{C}$ limit corresponds to a maximum possible ER of only 0.33 . Different maximum ERs could be expected for other fuels and gasification conditions. For fuels with different ash concentration and makeup, agglomeration problems might present themselves at different temperatures due to changes in ash accumulation rates in the bed and the melting point of the ash eutectic.

The effect of ER on permanent gas composition is shown in Figure 8. The percent concentrations are stated on a dry "inert free" basis, since the He content of the syngas originates only from the tracer and essentially all of the $\mathrm{N}_{2}$ comes from the feed system purge. In practice, the $\mathrm{N}_{2}$ content varied from 2$10 \% \mathrm{vol} / \mathrm{vol}$ dry basis, and He content varied from $1.0-2.5 \% \mathrm{vol} / \mathrm{vol}$ dry basis. The thermodynamic equilibrium concentrations of each of the permanent gases have been superimposed onto the plots for comparison.

Thermodynamic equilibrium calculations predicted that $\mathrm{CH}_{4}$ should only be present when $\mathrm{ER}$ is less than 0.25 , however significant amounts of methane were measured for all ER levels tested. The experimental results demonstrated a continual steady decline in $\mathrm{CH}_{4}$, indicating a slow approach toward equilibrium as ER (and reactor temperature) increased. Though $\mathrm{CO}_{2}$ remained far away from predicted equilibrium concentrations for all ER levels tested, the increasing trend in $\mathrm{CO}_{2}$ was predicted by the trend of the equilibrium $\mathrm{CO}_{2}$ concentration results. The experimental results demonstrated a steady increase in $\mathrm{H}_{2}$, and generally declining $\mathrm{CO}$ concentration as ER increased. Both species remained far away from equilibrium predictions for all ER levels tested. A likely reaction pathway for converting the methane to other species is the methanation reaction (Eq 1) [3]. The back reaction of the methanation reaction is endothermic; thus, increasing gasification temperature and steam availability would be expected to reduce $\mathrm{CH}_{4}$ and increase $\mathrm{H}_{2}$.

$\mathrm{CO}+3 \mathrm{H}_{2} \leftrightarrow \mathrm{CH}_{4}+\mathrm{H}_{2} \mathrm{O}$

Eq 1

One would also expect $\mathrm{CO}$ concentration to increase as $\mathrm{CH}_{4}$ is consumed by the methanation reaction; however, our results demonstrated a downward trend in $\mathrm{CO}$ concentration. This is likely due to destruction of CO via the water-gas shift reaction (Eq 2) [3]. The water-gas shift reaction is exothermic, and would be slowed by increasing gasification temperature that accompanies increasing ER; however, the increasing steam flow to the reactor would encourage the destruction of $\mathrm{CO}$ and production of $\mathrm{H}_{2}$.

$\mathrm{CO}+\mathrm{H}_{2} \mathrm{O} \leftrightarrow \mathrm{CO}_{2}+\mathrm{H}_{2}$

Eq 2 
The experimental results of Meng et al. [6] and Siedlecki and de Jong [10] displayed the same upward trend in $\mathrm{H}_{2}$.

The effect of ER on $C_{2}$ hydrocarbons is shown in Figure 9. Ethylene was generally the most prevalent $C_{2}$ hydrocarbon, although small amounts of $\mathrm{C}_{2} \mathrm{H}_{6}$ and $\mathrm{C}_{2} \mathrm{H}_{2}$ were also present. The trend of $\mathrm{C}_{2} \mathrm{H}_{4}$ is most significant, declining steeply from $4.2 \%$ to only $0.7 \%$ as ER was increased. This decline represents an approach to equilibrium conditions, as no significant amounts of $\mathrm{C}_{2}$ hydrocarbons were predicted by the equilibrium calculations. Reactions similar to methanation are probably responsible for the downward trends, since they would be similarly endothermic and accelerated by increased temperatures and steam presence.

The effect of ER on heavy tar is demonstrated in Figure 10. Heavy tar content decreased steadily from 43 to $17 \mathrm{~g} / \mathrm{N}-\mathrm{m}^{3}$ with increasing ER. This range is comparable to values reported by Gil et al. [5] for similar operating conditions. The decline in tar concentration with increasing ER is consistent with an approach to equilibrium for which no tar is expected among gasification products. Endothermic tar cracking and steam reforming reactions are responsible for destruction of $\operatorname{tar}[22]$.

The effect of ER on water content of the syngas is shown in Figure 11. The thermodynamic equilibrium concentration of water for the same conditions is superimposed onto the plot for comparison. Interestingly, the experimental trend in water content decreased as ER was increased from 0.21 , reached a minimum near $E R=0.26$, and then increased again for higher $E R s$. This minimum was not predicted by the equilibrium modeling results, which show $\mathrm{H}_{2} \mathrm{O}$ content increasing steadily as ER is increased, mostly due to increased amounts of steam coming in as fluidizing agent. The downward trend of the steam content from an ER of 0.21-0.25 is probably caused by the participation of steam in several reactions including methanation [3], water-gas shift [3], and reforming of $C_{2}$ hydrocarbons and tars [22]. These endothermic steam consuming reactions might be expected to first increase with ER (and temperature), but then slow as the supply of hydrocarbon reactants is depleted, as is the case at high $E R$, accounting for the trend in water content.

The effect of ER on char content of the raw syngas is shown in Figure 12. In general, char content decreased with ER. This reflects conditions more closely approaching equilibrium as temperatures increased, as equilibrium predicted zero solid carbon. This result is in accord with expectations for higher levels of $\mathrm{O}_{2}$ and $\mathrm{H}_{2} \mathrm{O}$ in the gasifier and higher reactor temperature [3]. Surprising, the char concentration increased dramatically at the highest ER (0.38). This unexpected result may reflect increasing elutriation of char due to increased attrition in the fluidized bed in combination with the higher superficial gas flow velocity through the reactor. It may simply be an artifact of the decreased run time for this particular gasification trial, which was terminated after only 30 minutes of steady state operation due to bed agglomeration. Further experiments at high ER would be required to resolve this question.

Equilibrium calculations predicted that molecular nitrogen $\left(\mathrm{N}_{2}\right)$ should be the only significant product of the FBN, amounting to about $0.45 \%$ vol/vol dry basis concentration for all ER levels. Despite this, 
significant amounts of $\mathrm{NH}_{3}$ and $\mathrm{HCN}$ were measured for all ER levels tested. The effect of ER on the yield of $\mathrm{NH}_{3}$ and $\mathrm{HCN}$ as a percentage of fuel bound nitrogen (FBN) in the biomass is illustrated in Figure 13. The yield of $\mathrm{NH}_{3}$ declined from about $50 \%$ to $32 \%$ of FBN as ER increased from 0.21 to 0.32 , which corresponds to dry-basis concentrations in the syngas of $1 \underline{0}, 000 \mathrm{ppm}$ and $5800 \mathrm{ppm}$, respectively. These concentrations are far higher than predicted for thermodynamic equilibrium, which indicates that the yield of $\mathrm{NH}_{3}$ should be less than $0.17 \%$ (15 ppm concentration) for ER between 0.21 and 0.38 .

This trend cannot be directly compared to previous gasification studies, which have not studied the response of nitrogenous species to ER for oxygen/steam environments. Most air-blown gasification studies using fluidized bed reactors have documented increasing concentrations of $\mathrm{NH}_{3}$ as $\mathrm{ER}$ and/or temperature are increased $[21,23,24,25,26,27]$. We hypothesize that these generally upward trends are due to increased release of $\mathrm{NH}_{3}$ from tar and char as carbon conversion increased, which is the subject of a future study. For the conditions explored in the present study, it appears that increases in ER and temperature accelerated $\mathrm{NH}_{3}$ to $\mathrm{N}_{2}$ conversion pathways more strongly than $\mathrm{NH}_{3}$ release pathways. These reactions are predicted by homogeneous gas reaction kinetics; a detailed overview of these mechanisms has been presented by Leppälahti and Koljonen [28].

The yield of HCN declined from $14 \%$ to $2.6 \%$ as ER was increased, corresponding to concentrations of 2500-440 ppm. The data showed large variations for the replicated runs at ER of 0.25 . During the course of the study, it was discovered that aqueous cyanide samples are prone to aging, with significant declines in cyanide ion concentrations over the course of several weeks of sample storage. Other researchers have previously noted this phenomenon [17]. In fact, the lowest measured HCN yield in the present study (one of the replications at ER of 0.25 ) was not analyzed until after nine weeks of storage in contrast to shorter delays for the other six samples. Even without assuming that this lowest HCN yield is an underestimate, an ANOVA statistical analysis on the linear regression of HCN yield data indicated a $\mathrm{p}$ value of 0.045 , indicating a likely inverse correlation between $\mathrm{HCN}$ yield and ER.

All of the HCN yields measured in the present study were higher by one to two orders of magnitude compared to three previous studies of $\mathrm{HCN}$ in biomass-derived syngas [24, 29, 30]. In contrast, three other studies have found $\mathrm{HCN}$ yields comparable to ours. Kurkela et al. [31] conducted straw gasification and found $\mathrm{HCN}$ yields of $4-14 \%$ of FBN. de Jong et al. [32,33] conducted wood pellet and miscanthus gasification and found yields of $0-14 \%$. We think this discrepancy is the result of inadequate sampling methodology used in the studies that reported much lower HCN yield, all of which used acidic impingers for trapping $\mathrm{NH}_{3}$ upstream of $\mathrm{HCN}$ impingers. This series sampling overlooked the possibility that the $\mathrm{NH}_{3}$ impinger absorbed both $\mathrm{NH}_{3}$ and $\mathrm{HCN}$. The importance of using separate sampling trains for these two forms of inorganic nitrogen in the syngas is the subject of a future paper.

Hydrogen cyanide concentrations of up to $2500 \mathrm{ppm}$ in the syngas for switchgrass gasification have important safety implications. Concentrations as low as 50 ppm are considered immediately hazardous to human health [34]. The nitrogen content of the switchgrass featured in the present study is $0.91 \%$, which is modest compared to other potential gasification feedstocks such as distillers grains (5.52\%) [6], sewage sludge (7.06\%) [35], and verge grass (lawn clippings) (2.47\%) [35]. 
The effect of ER on several other gasification performance parameters, including carbon conversion, gas yield, syngas energy content, and cold gas efficiency, are shown in Table 3. Gas yields varied from 0.82 to $1.01 \mathrm{~N}-\mathrm{m}^{3} / \mathrm{kg}$ dry ash-free (daf) biomass, and generally increased with ER. The higher heating value $(\mathrm{HHV})$ of the dry syngas varied from 8.8 to $13.2 \mathrm{MJ} / \mathrm{N}-\mathrm{m}^{3}$, with the greatest heating values occurring at the lowest ERs. Cold gas efficiency varied from $42-64 \%$ with the highest efficiency occurring at ERs between 0.24 and 0.28 . Percent carbon conversion (\%CC) was computed from the quantity of carbon fed to the reactor in the biomass $\left(C_{b}\right)$ and the quantity of carbon in the produced char, $C_{c}$ via Eq 3 . Carbon conversion varied from $74-89 \%$ with no clear relationship to ER evident. Mass balance closures for the eight runs were $91-117 \%$.

$\% C C=\left(\frac{C_{b}-C_{c}}{C_{b}}\right) * 100 \%$

Eq 3

The gasification reactor was operated for approximately 200 hours for its initial commissioning and collection of the data reported in the present study. The reactor bed was disassembled upon conclusion of testing for inspection. There were no signs of refractory erosion, and very little refractory cracking had occurred.

\subsection{Cleanup System Performance}

Particulate removal efficiency of the pair of gas cyclones was determined by comparing the amounts of char trapped in each of the two cyclone catches with the char concentration measured by isokinetic sampling at port A (Figure 4). The combined removal efficiency of the two cyclones varied from $91 \%$ to $97 \%$ for the tests conducted for this study. This is comparable to the generally recognized efficiency for well-designed gas cyclones [36].

The performance of the oil scrubber is shown in Table 4. It was found that nearly all of the heavy tars were removed by the tar scrubber, resulting in $60-80 \%$ overall tar removal efficiency. The novel SPME tar measurement method demonstrated that most of the unremoved tar was benzene. Smaller amounts of toluene, styrene, and indene were also found. Traces of the heavier naphthalenes were occasionally observed during unintentional deviations in the operating conditions of the tar scrubber.

Operating the tar scrubber at lower temperature would likely have improved tar removal efficiency by increasing the number of light tars collected. In practice, this would have also condensed water in the oil, which is undesirable from the standpoint of recovering and disposing of the tars. More elaborate multi-stage tar removal systems have been developed, such as described by Zwart et al. [37], capable of removing up to $99 \%$ of light tars such as phenolics monomers and single-ring aromatic hydrocarbons 
along with almost complete removal of heavy tar compounds. These systems are highly complex though, requiring three or more unit operations and multiple types of scrubbing liquids. The additional complexity may not be justified for all applications of syngas.

The performance of the sulfur and ammonia removal systems is reported in Table 5. All concentrations here are given on a wet syngas basis and including added gas since data on inputs of steam, $\mathrm{N}_{2}$, and $\mathrm{He}$ were unavailable at the time these experiments were performed. The sulfur scrubbers performed very well, removing more than $99.9 \%$ of $\mathrm{H}_{2} \mathrm{~S}$, and dropping the concentration of all sulfur species below 1 $\mathrm{ppm}$. This compares well with other solid phase adsorption processes used commercially. For example, copper and zinc based materials remove more than $99 \%$ of sulfur compounds [36]. The sorbent system also removed $\mathrm{COS}$ and $\mathrm{CS}_{2}$. As shown in Table 5, COS was reduced from 20-49 ppm to 0.3-0.6 ppm (97$99 \%$ removal) and $\mathrm{CS}_{2}$ was reduced from 0.2-1 ppm to less than $0.01 \mathrm{ppm}$ (greater than $95 \%$ removal). The sulfur removal system typically was operated for only a few hours at a time, because these tests were performed in conjunction with relatively short shakedown trials of the tar scrubbing system.

The $\mathrm{NH}_{3}$ scrubber was also very efficient, removing $\mathrm{NH}_{3}$ by $99.9 \%$, resulting in a final gas concentration of less than $1 \mathrm{ppm}$. This was consistent with previous studies, which showed that merely condensing water from syngas can remove up to $90 \%$ of $\mathrm{NH}_{3}$ [38].

\section{Conclusions}

The use of electrical cartridge heaters embedded in ceramic insulation surrounding the fluidized bed of a $25 \mathrm{~kg} / \mathrm{h}$ biomass gasifier was able to simulate adiabatic steam/oxygen gasification for temperatures as high $900^{\circ} \mathrm{C}$. This allowed switchgrass to be gasified at ERs between 0.21 and 0.32 . At higher ERs, the cartridge heaters were unable to operate at sufficiently high temperatures to produce a temperature barrier against heat loss from the gasifying biomass. Agglomeration of bed material also limited temperature and $E R$ to about $900^{\circ} \mathrm{C}$ and 0.33 respectively, despite the use of limestone in the bed to ameliorate this phenomenon. The observed behavior of non-condensable gases suggested that methanation and the water-gas shift reaction became increasingly active as ER increased. This study is among the first to report $\mathrm{NH}_{3}$ and $\mathrm{HCN}$ yields from $\mathrm{FBN}$ for oxygen and steam blown gasification of biomass. The yields of both were found to decrease with increasing ER. HCN was produced at concentrations that are as much as an order of magnitude larger than reported in several previous studies of biomass gasification. This has important implications for syngas clean-up and safe operation of gasifiers using feedstocks with high FBN content.

The gas cleanup system was effective in reducing the level of contaminants in syngas although none of the unit operations had been optimized. The oil scrubber effectively removed all the heavy tars, resulting in overall tar removal efficiency as high as $80 \%$. Light tars consisting of mostly phenolic monomers and single-ring aromatic compounds are difficult to remove with operating below the dew point of water, which can complicate recovery of tar for disposal. Both the sulfur and nitrogen scrubbing systems removed over $99.9 \%$ of these contaminants. 


\section{Acknowledgements}

Financial support for this project was provided by Phillips 66 and the United States Department of Energy.

The authors would like to graciously extend special thanks to Doug Bull for designing the feed system and providing guidance on the design of the gasifier, Dr. Alexandru Platon for guidance in designing the gas cleanup equipment, and Dr. Samuel Jones for project management guidance. The authors are also grateful for engineering support provided by Lysle Whitmer and Andrew Friend. The authors would like to thank Jordan Funkhouser, Andrew Larson, Adam Bohl, Memo Hinckley, Brandon Huth, Clark Ennis, and Dan Hunting for providing research assistance. Recognition is deserved by Jacob Broer for help with sample analysis. The authors are grateful to have had useful conversations with Dan Hampton, John Dawley, Rick Ennis, James Graefe, Doug Owens, Brian Bettini, Ken Gielow, Sean DeGeest, Gary Ballard, and Andrew Suby during the design, construction, and commissioning phases of this project. The authors would finally like to thank Badger Mining Corporation and ILC Resources for donating the bed materials for this study. 


\section{Works Cited}

[1] P. Spath and D. Dayton, "Preliminary Screening - Technical and Economic Assessment of Synthesis Gas to Fuels and Chemicals with Emphasis on the Potential for Biomass-Dervied Syngas," NREL Technical Report, no. NREL/TP-510-34929, 2003.

[2] R. L. Bain and K. Broer, "Gasification," in Thermochemical Processing of Biomass, R. C. Brown, Ed., Chichester, John Wiley \& Sons, Ltd, 2011, pp. 47-77.

[3] R. C. Brown, Biorenewable Resources: Engineering New Products from Agriculture, Ames: lowa State Press, 2003, p. 149.

[4] International Energy Agency, "Key World Energy Statistics," Internation Energy Agency, Paris, 2013.

[5] J. Gil, M. P. Aznar, M. A. Cabellero, E. Frances and J. Corella, "Biomass gasfication in fluidized bed at pilot scale with steam-oxygen mixtures. Product distribution for very different operating conditions.," Energy \& Fuels, vol. 11, no. 6, pp. 1109-1118, 1997.

[6] X. Meng, W. de Jong, N. Fu and A. H. Verbooijen, "Biomass gasification in a 100kWth steam-oxygen blown fluidized bed gasifier: Effects of operational conditions on product gas distribution and tar formation," Biomass and Bioenergy, vol. 35, pp. 2910-2924, 2011.

[7] F. Pinto, R. N. André, C. Franco, C. Carolino, R. Costa, M. Miranda and I. Gulyurtlu, "Comparison of a pilot scale gasification installation performance when air or oxygen is used as gasification medium 1. Tars and gaseous hydrocarbons formation," Fuel, vol. 101, pp. 102-114, 2012.

[8] F. Pinto, R. N. André, H. Lopes, C. Franco, C. Carolino, M. Galhetas, M. Miranda and I. Gulyurtlu, "Comparison of a pilot scale gasification installation performance when air or oxygen is used as gasification medium 2. Sulfur and nitrogen compounds abatement," Fuel, vol. 97, pp. 770-782, 2012.

[9] M. Campoy, A. Gomez-Barea, F. B. Vidal and P. Ollero, "Air-steam gasification of biomass in a fluidised bed: Process optimized by enriched air," Fuel Processing Technology, vol. 90, pp. 677-685, 2009.

[10] M. Siedlecki and W. de Jong, "Biomass gasification as the first hot step in clean gas production process - gas quality optimization and primary tar reduction measures in a $100 \mathrm{~kW}$ thermal input steam-oxygen blown CFB gasifier," Biomass and Bioenergy, vol. 35, pp. S40-S62, 2011.

[11] S. Turn, C. Kinoshita, Z. Zhang, D. Ishimura and J. Zhou, "An experimental investigation of hydrogen production from biomass generation," International Journal of Hydrogen Energy, vol. 23, no. 8, pp. 
641-648, 1998.

[12] C. Van Huynh and S.-C. Kong, "Performance characteristics of a pilot-scale biomass gasifier using oxygen-enriched air and steam," Fuel, vol. 103, pp. 987-996, 2013.

[13] C. Stairmand, "The role of the cyclone in reducing atmospheric pollution," Chemistry \& Industry, vol. 42, pp. 1324-1330, 1955.

[14] P. J. Woolcock, "Development and application of a rapid sampling technique for identification and quantification of compounds in high temperature process gas streams produced from biomass gasification and pyrolysis.," PhD Dissertation, lowa State University, 2013.

[15] S. Q. Turn, C. M. Kinoshita, D. M. Ishimura and J. Zhou, "The fate of inorganic constituents of biomass in fluidized bed gasification," Fuel, vol. 77, no. 3, pp. 135-146, 1998.

[16] P. Basu, Combustion and Gasification in Fluidized Beds, Boca Raton, FL U.S.A.: CRC Press, 2006.

[17] M. Xu, R. C. Brown, G. Norton and J. Smeenk, "Comparison of a Solvent-Free Tar Quantification Method to the International Energy Agency's Tar Measurement Protocol," Energy \& Fuels, pp. p 2509-2513, 2005.

[18] P. J. Woolcock, J. A. Koziel, P. A. Johnston and R. C. Brown, "Analysis of trace contaminents in hot gas streams using time-weighted average solid-phase microextraction: Proof of concept.," Journal of Chromatography, vol. 1281, no. 1, 2013.

[19] The Standard Methods Organization, "4500-NH3 Nitrogen (Ammonia)," 2006. [Online]. Available: http://www.standardmethods.org/Store/ProductView.cfm?ProductID=191. [Accessed 11 June 2014].

[20] T. B. Reed, Biomass Gasification: Principles and Technology, Park Ridge: Noyes Data Corporation, 1981.

[21] N. Padban, "PFB Air gasification of biomass, investigation of product formation and problematic issues related to ammonia, tar and alkali," PhD Thesis, Lund University, Department of Chemical Engineering II, Sweden, 2000.

[22] C. C. Xu, J. Donald, E. Byambajav and Y. Ohtsuka, "Recent advances in catalysts for hot-gas removal of tar and NH3 from biomass gasification," Fuel, vol. 89, pp. 1784-1795, 2010.

[23] M. Berg, P. Vriesman, E. Heginuz, K. Sjöström and B.-G. Espenäs, "Fuel-bound nitrogen conversion: results from gasification of biomass in two different small scale fluidized beds," in Progress in Thermochemical Biomass Conversion, Seefeld, Austria, Blackwell Science Ltd, 2001, pp. 322-332. 
[24] P. Vriesman, E. Heginuz and K. Sjöström, "Biomass gasification in a laboratory-scale AFBG: influence of the location of the feeding point on the fuel-N conversion," Fuel, vol. 79, pp. 1371-1378, 2000.

[25] C. Rosén, "Fundamentals of pressurized gasification of biomass," Developments in thermochemical biomass conversion, vol. 2, pp. 817-827, 1997.

[26] W. Zhang, X. Dai, U. Söderlind, C. Wu and X. Luo, "A preliminary test on an industrial biomass CFB gasifier.," in Proceedings of the 12th European Biomass Conference "Biomass for Energy, Industry, and Climate Protection, Amsterdam, 2002.

[27] P. Abelha, I. Gulyurtlu and I. Cabrita, "Release of nitrogen precursors from coal and biomass residues in a bubbling fluidized bed," Energy \& Fuels, vol. 22, pp. 363-371, 2008.

[28] J. Leppälahti and T. Koljonen, "Nitrogen evolution from coal, peat and wood during gasification: Literature review," Fuel Processing Technology, vol. 43, pp. 1-45, 1995.

[29] J. Zhou, S. M. Masutani, D. M. Ishimura, S. Q. Turn and C. M. Kinoshita, "Release of Fuel-Bound Nitrogen during Biomass Gasification," Ind. Eng. Chem. Res., vol. 39, pp. 626-634, 2000.

[30] Q.-Z. Yu, C. Brage, G.-X. Chen and K. Sjöström, "The fate of fuel-nitrogen during gasification of biomass in a pressurised fluidised bed gasifier," Fuel, vol. 86, pp. 611-618, 2007.

[31] E. Kurkela, J. Laatikainen-Luntama, P. Ståhlberg and A. Moilanen, "Pressurised fluidised-bed gasification experiments with biomass, peat and coal at VTT in 1991-1994 Part 3. Gasification of Danish wheat straw and coal," VTT Publications, vol. 291, pp. 3-41, 1996.

[32] W. de Jong, Ö. Ünal, J. Andries, K. R. G. Hein and H. Spliethoff, "Thermochemical conversion of brown coal and biomass in a pressurise fluidised bed gasifier with hot gas filtration using ceramic channel filters: measurements and gasifier modelling," Applied Energy, vol. 74, pp. 425-437, 2003.

[33] W. de Jong, Ö. Ünal, J. Andries, K. R. G. Hein and H. Spliethoff, "Biomass and fossil fuel conversion by pressurised fluidised bed gasification using hot gas ceramic filters as gas cleaning," Biomass \& Bioenergy, vol. 25, pp. 59-83, 2003.

[34] National Institute for Occupational Safety and Health, "Hydrogen Cyanide," May 1994. [Online]. Available: http://www.cdc.gov/niosh/idlh/74908.html. [Accessed 7 April 2014].

[35] A. van der Drift, J. van Doorn and J. W. Vermeulen, "Ten residual biomass fuels for circulating fluidized-bed gasification," Biomass \& Bioenergy, vol. 20, pp. 45-56, 2001.

[36] P. J. Woolcock and R. C. Brown, "A review of cleaning technologies for biomass-derived syngas," Biomass and Bioenergy, vol. 52, pp. 54-84, 2013. 
[37] R. W. R. Zwart, A. van der Drift, A. Bos, H. J. M. Visser, M. K. Cieplik and H. W. J. Könemann, "OilBased Gas Washing - Flexible Tar Removal for High-Efficient Production of Clean Heat and Power as Well as Sustainable Fuels and Chemicals," Environmental Progress \& Sustainable Energy, vol. 28, no. 3, pp. 324-335, 2009.

[38] F. Pinto, H. Lopes, R. N. André, M. Dias, I. Gulyartlu and I. Cabrita, "Effect of Experimental Conditions on Gas Quality and Solids Produced by Sewage Sludge Cogasification. 1. Sewage sludge mixed with coal," Energy \& Fuels, vol. 21, pp. 2737-2745, 2007. 
Table 1. A summary of oxygen/steam and enriched air/steam biomass gasification studies (EA - Enriched Air, BFB - Bubbling Fluidized Bed, CFB - Circulating Fluidized Bed, ER - Equivalence Ratio, T - Temperature, OC Oxygen Concentration of fluidizing agents, SBR - Steam to Biomass Ratio, BM - bed material, CBR Coal/Biomass Ratio)

Table 2. Switchgrass fuel proximate and ultimate analyses (uncertainty reflects $95 \%$ confidence interval).

Table 3. Other gasifier performance parameters that were measured. Fluidizing agent was $50 \%$ mass $\mathrm{O}_{2}$, balanced with steam. Data are reported on a dry inert-free basis.

Table 4. Tar removal performance of the oil scrubber during three select gasification tests.

Table 5. Major sulfur compounds and $\mathrm{NH}_{3}$ removal efficiency (wet basis, inerts included). 
Figure 1. The new feed system and fluidized bed gasifier at lowa State University.

Figure 2. A photo of: (1) The pressurized feed system and (2) The $20 \mathrm{~kg} / \mathrm{h}$ fluidized bed gasifier.

Figure 3. The gasification reactor consisted of a carbon steel pressure vessel lined with first a layer of microporous insulation, followed by a layer of refractory. Six wells were included in the refractory for accommodating insertion heaters.

Figure 4. The gas cleaning system consisted of: (1) Oil scrubbing column for removing fine char and tars, (2) Oil decanter tank for allowing collected solids to settle out of oil, (3) Oil circulation pump, (4) Oil cooling heat exchanger, (5) Oil filter, (6) Electrical syngas circulation heater, (7) Packed bed sulfur adsorbent canisters, (8) Water scrubber for ammonia removal

Figure 5. A photo of: (1) The oil scrubbing column, (2) Packed bed sulfur adsorbent canisters, and (3) Water scrubber for ammonia removal. Vessels are shown with all insulation and heat tracing/jacketing removed.

Figure 6. Sample line setup for measurement of char, heavy tar, water, and permanent gas composition of the syngas: (1) $53 \mathrm{~mm}$ inner-diameter (ID) raw syngas pipeline, (2) Isokinetic sampling probe located at sampling port A, (3) $8 \mathrm{~mm}$ ID stainless steel tubing heat traced to $450^{\circ} \mathrm{C}$, (4) Quartz thimble filter inside tube furnace at $450^{\circ} \mathrm{C}$, (5) $8 \mathrm{~mm}$ ID tubing at $450^{\circ} \mathrm{C},(6)$ Tar collection pressure cooker at $100-115^{\circ} \mathrm{C},(7)$ Stainless steel needle valve and $8 \mathrm{~mm}$ ID tubing heated to $120^{\circ} \mathrm{C}$, (8) Tubing tee and septum for SPME sampling of light tars, (9) Two $500 \mathrm{~mL}$ glass impingers in a water-ice bath for water collection and wet chemical measurements of ammonia and hydrogen cyanide, (10) Dessicate canister for final water aerosol removal, (11) Diaphragm vacuum pump, (12) Rotameter with integral control valve, (13) Varian CP-4900 micro gas chromatograph, (14) Drum-type total flow gas meter, (15) To exhaust.

Figure 7. The effect of ER on adiabatic reactor temperature. Fluidizing agent was 50 wt\% $\mathrm{O}_{2}$, balanced with steam. Temperature measurements were taken from a thermocouple inserted into the fluidized bed, $110 \mathrm{~mm}$ above the perforated plate.

Figure 8. The effect of ER on $\mathrm{H}_{2}, \mathrm{CO}, \mathrm{CO}_{2}$, and $\mathrm{CH}_{4}$ concentrations . Fluidizing agent was 50 wt\% $\mathrm{O}_{2}$, balanced with steam. Values are reported on a \% vol/vol dry, inert-free basis. The results from thermodynamic equilibrium modeling for the same reactor conditions are included for comparison.

Figure 9. The effect of ER on concentrations of $\mathrm{C}_{2}$ hydrocarbons. Fluidizing agent was 50 wt $\% \mathrm{O}_{2}$, balanced with steam. Values are reported on a \% vol/vol dry, inert-free basis. The results from thermodynamic equilibrium modeling demonstrated essentially no production of $C_{2}$ hydrocarbons.

Figure 10. The effect of ER on heavy tar concentration. Fluidizing agent was 50 wt\% $\mathrm{O}_{2}$, balanced with steam. Values are reported on a dry, inert-free basis. The results from thermodynamic equilibrium modeling for the same reactor conditions are included for comparison.

Figure 11. The effect of ER on the water content of the syngas. Fluidizing agent was 50 wt\% $\mathrm{O}_{2}$, balanced with steam. Values are reported on a $\%$ vol/vol wet, inert-free basis.

Figure 12. The effect of ER on the syngas char content. Fluidizing agent was 50 wt\% $\mathrm{O}_{2}$, balanced with steam. Values are reported on a dry, inert-free basis.

Figure 13. The effect of ER on the yields of $\mathrm{NH}_{3}$ and $\mathrm{HCN}$ (as a percentage of the FBN). Fluidizing agent was 50 wt\% $\mathrm{O}_{2}$, balanced with steam. 


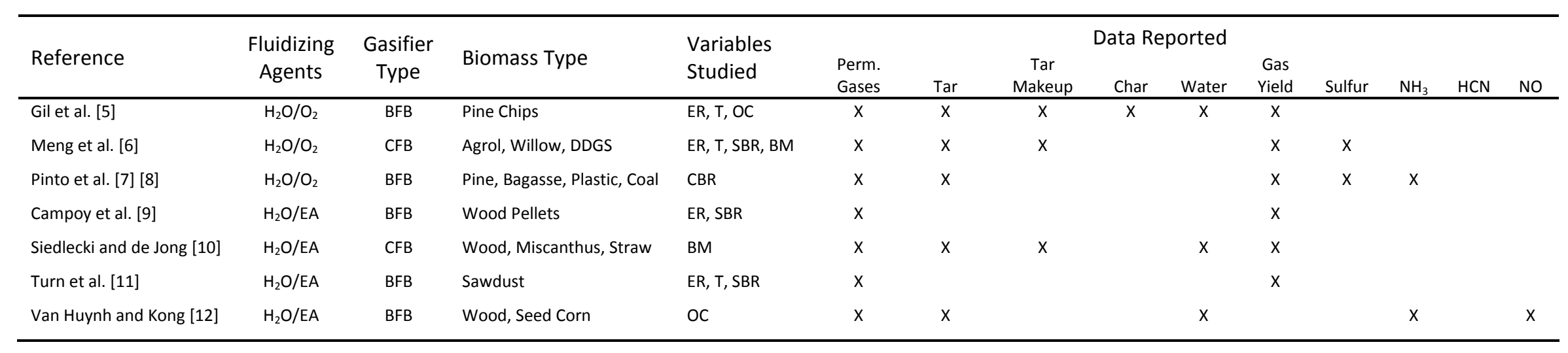




\begin{tabular}{|lc|}
\hline Proximate Analysis & (wt\%, as received) \\
Moisture & $8.26 \pm 0.08$ \\
Volatiles & $75.5 \pm 1.2$ \\
Fixed Carbon & $13.3 \pm 0.5$ \\
Ash & $5.8 \pm 0.8$ \\
& \\
Ultimate Analysis & (wt\%, dry basis) \\
C & $46.7 \pm 1.0$ \\
$\mathrm{H}$ & $4.99 \pm 0.08$ \\
$\mathrm{~N}$ & $0.86 \pm 0.10$ \\
& \\
$\mathrm{Al}$ & $0.03 \pm 0.01$ \\
$\mathrm{Ca}$ & $0.35 \pm 0.10$ \\
$\mathrm{Cl}$ & $1.49 \pm 0.14$ \\
$\mathrm{~K}$ & $2.55 \pm 0.11$ \\
$\mathrm{Fe}$ & $0.01 \pm 0.01$ \\
$\mathrm{Mg}$ & $0.20 \pm 0.02$ \\
$\mathrm{Na}$ & $0.03 \pm 0.00$ \\
$\mathrm{P}$ & $0.09 \pm 0.02$ \\
$\mathrm{~S}$ & $0.06 \pm 0.03$ \\
$\mathrm{Si}$ & $1.67 \pm 0.54$ \\
& \\
$\mathrm{O}$ (by difference) & 41.0 \\
\hline
\end{tabular}




\begin{tabular}{ccccc}
\hline $\begin{array}{c}\text { Equivalence } \\
\text { Ratio }\end{array}$ & $\begin{array}{c}\text { Dry gas yield } \\
\left(\mathrm{N}-\mathrm{m}^{3} / \mathrm{kg} \mathrm{daf}\right)\end{array}$ & $\begin{array}{c}\text { HHV syngas } \\
\left(\mathrm{MJ} / \mathrm{N}-\mathrm{m}^{3}\right)\end{array}$ & $\begin{array}{c}\text { Cold gas efficiency } \\
(\%)\end{array}$ & $\begin{array}{c}\text { Carbon Conversion } \\
(\%)\end{array}$ \\
\hline 0.21 & 0.82 & 12.8 & 53 & 77 \\
0.24 & 0.92 & 13.0 & 64 & 81 \\
0.25 & 1.01 & 11.5 & 58 & 89 \\
0.25 & 0.86 & 13.1 & 56 & 83 \\
0.28 & 0.92 & 12.6 & 59 & 82 \\
0.32 & 0.93 & 10.6 & 50 & 74 \\
0.38 & 0.96 & 8.8 & 42 & 76 \\
0.21 & 0.85 & 13.2 & 56 & 74 \\
\hline
\end{tabular}




\begin{tabular}{|c|c|c|c|c|c|c|}
\hline \multirow{2}{*}{$\begin{array}{l}\text { Equivalence } \\
\text { Ratio }\end{array}$} & \multirow{2}{*}{$\begin{array}{c}\text { Reactor } \\
\text { Temperature }\left({ }^{\circ} \mathrm{C}\right)\end{array}$} & \multicolumn{3}{|c|}{ Raw syngas tar $\left(\mathrm{g} / \mathrm{N}-\mathrm{m}^{3}\right)$} & \multirow{2}{*}{$\begin{array}{c}\text { Total tar after oil } \\
\text { scrubbing }\left(\mathrm{g} / \mathrm{N}-\mathrm{m}^{3}\right)\end{array}$} & \multirow{2}{*}{ Tar Removal (\%) } \\
\hline & & Heavy & Light & Total & & \\
\hline 0.21 & 705 & 43.4 & 12.7 & 56.1 & 8.8 & $84 \%$ \\
\hline 0.28 & 815 & 35.3 & 8.7 & 44.0 & 11.9 & $74 \%$ \\
\hline 0.32 & 880 & 29.1 & 13.7 & 42.8 & 8.5 & $80 \%$ \\
\hline
\end{tabular}




\begin{tabular}{lll}
\hline Compound & Before cleaning stage (ppm) & After cleaning stage (ppm) \\
\hline $\mathrm{H}_{2} \mathrm{~S}$ & $170-320$ & $0.02-0.2$ \\
$\mathrm{COS}$ & $20-49$ & $0.3-0.6$ \\
$\mathrm{CS}_{2}$ & $0.2-1$ & $<0.01$ \\
$\mathrm{NH}_{3}$ & $1270-2270$ & $<0.9$ \\
\hline
\end{tabular}




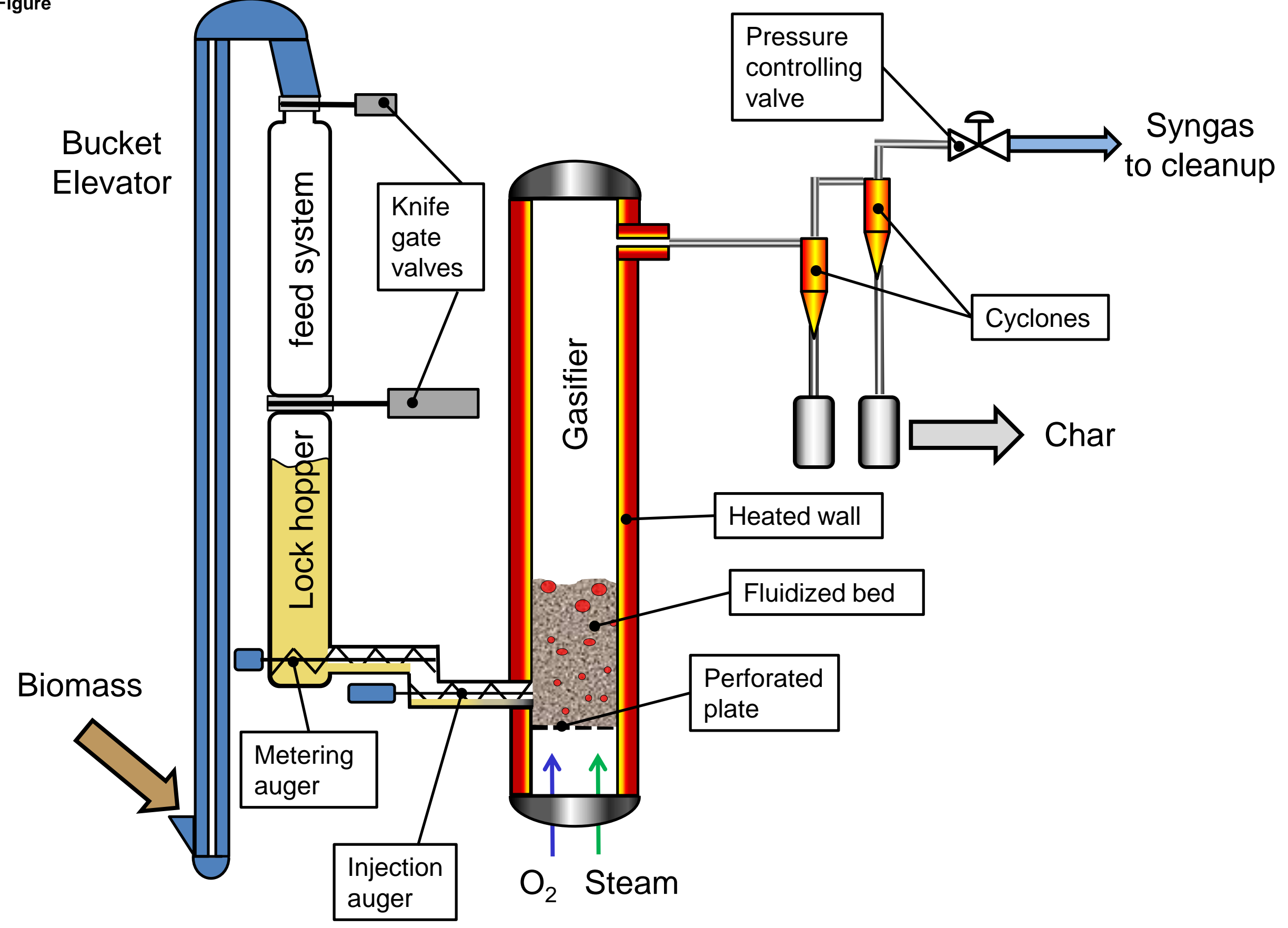




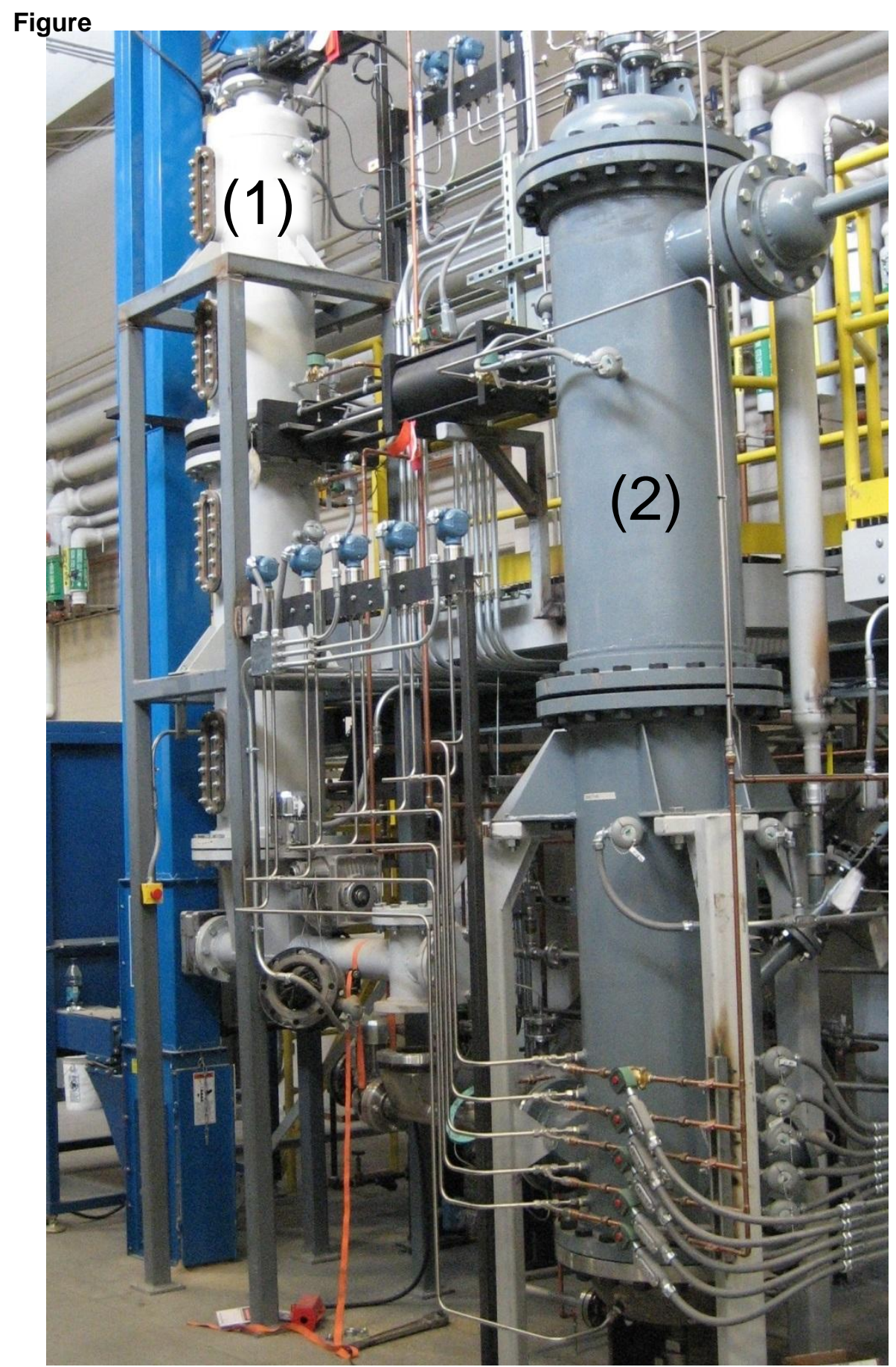

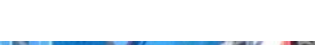

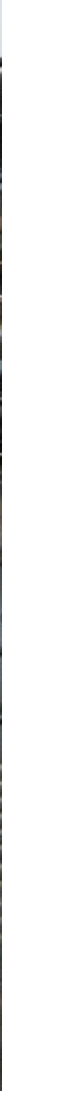

(1) 0

(

.




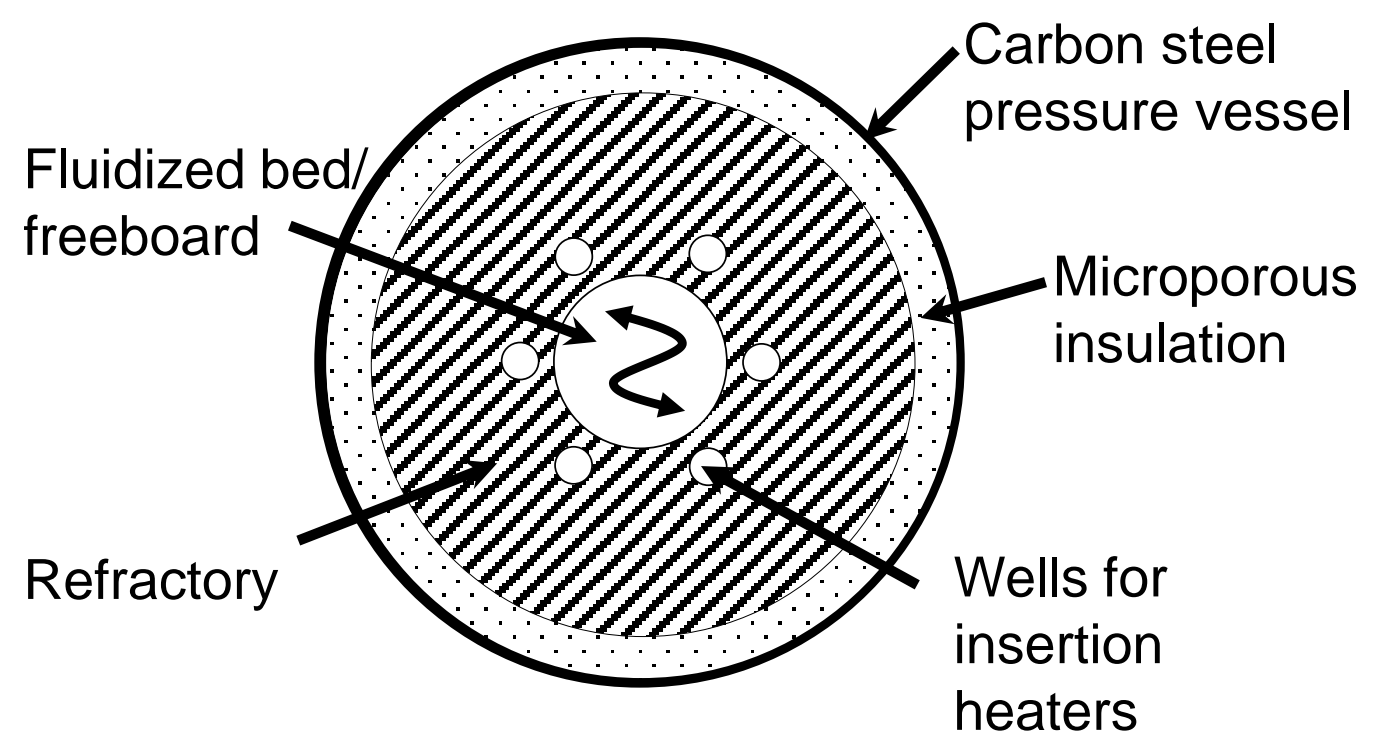




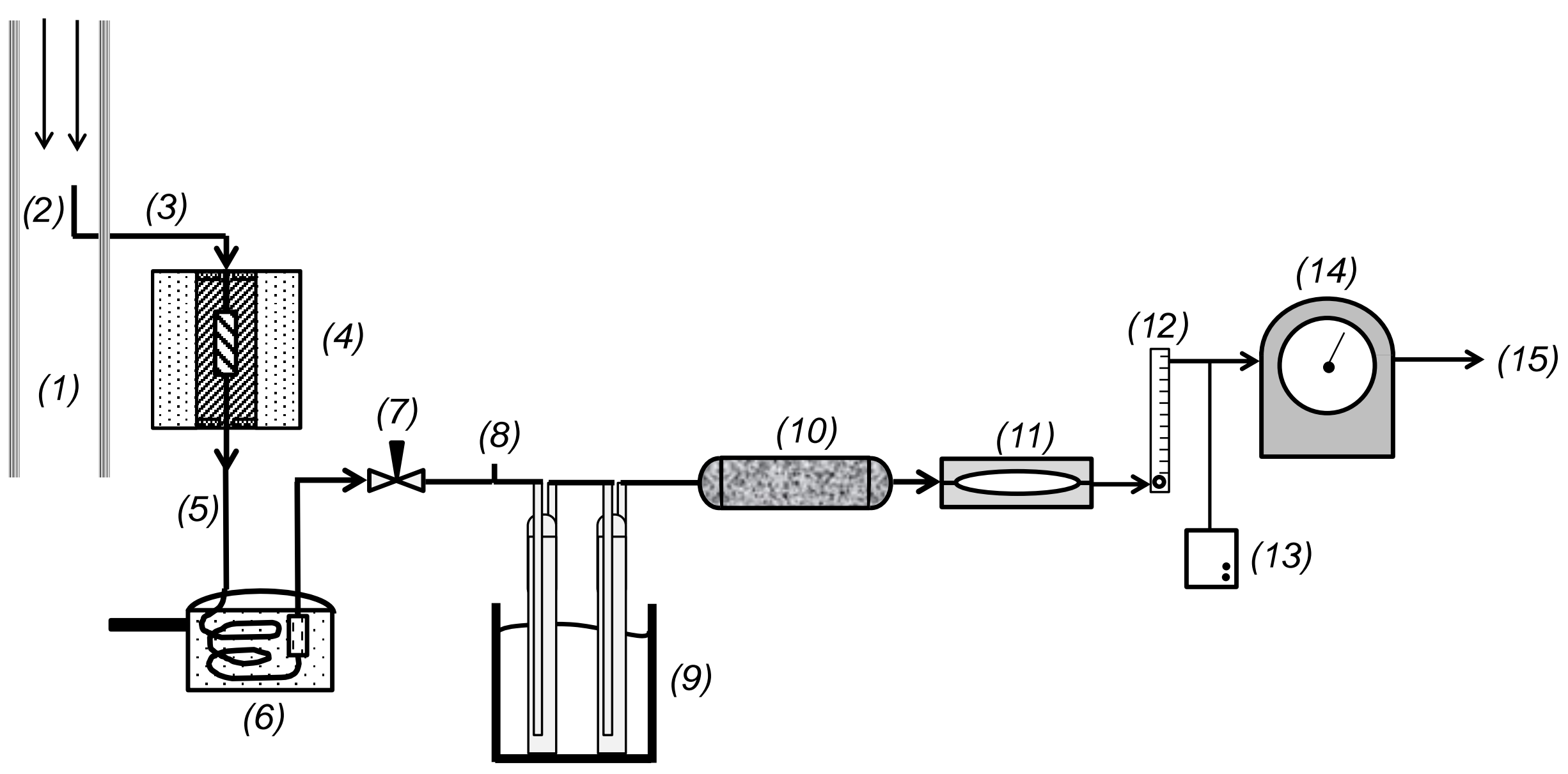



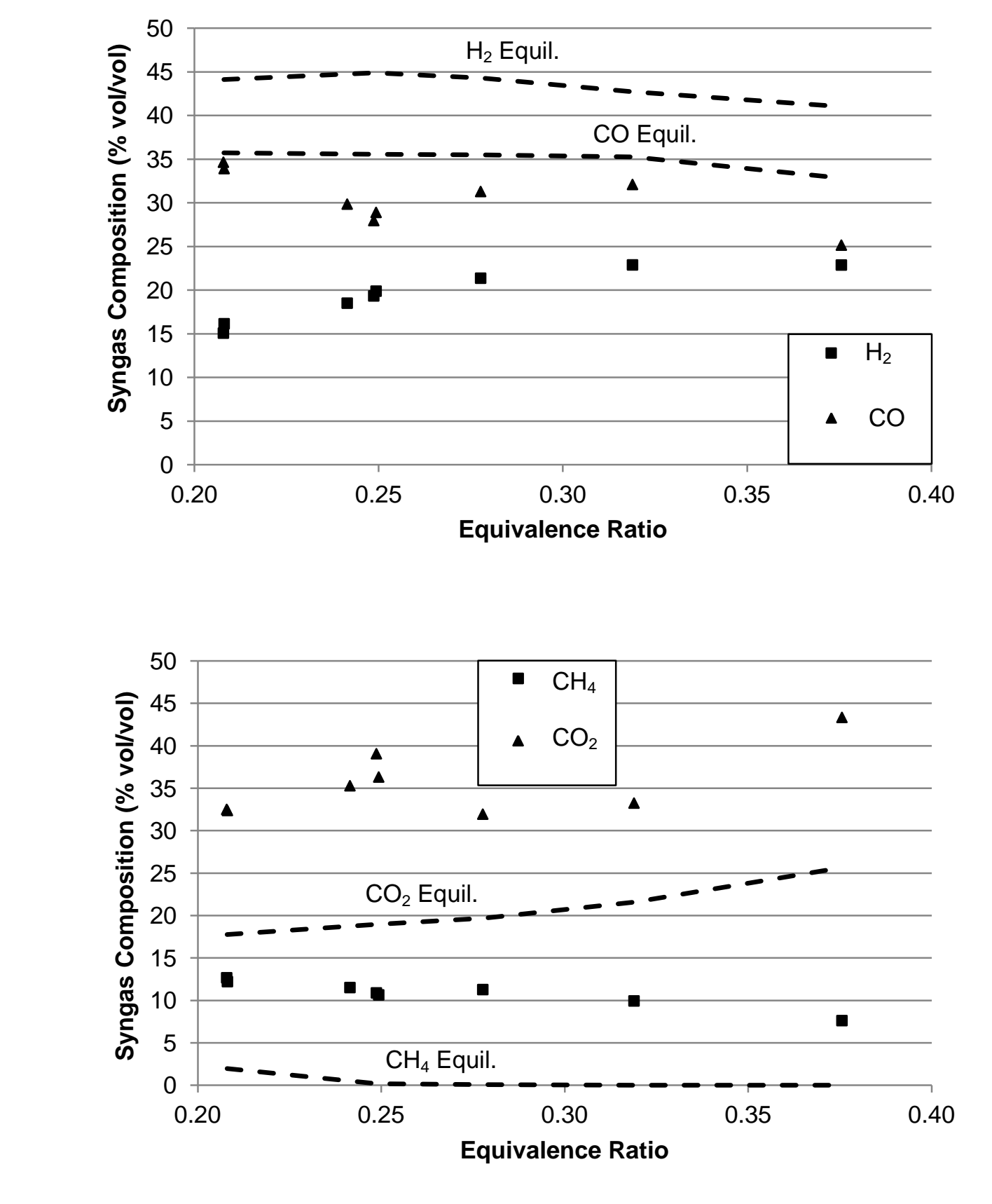

Equivalence Ratio

Equivalence Ratio

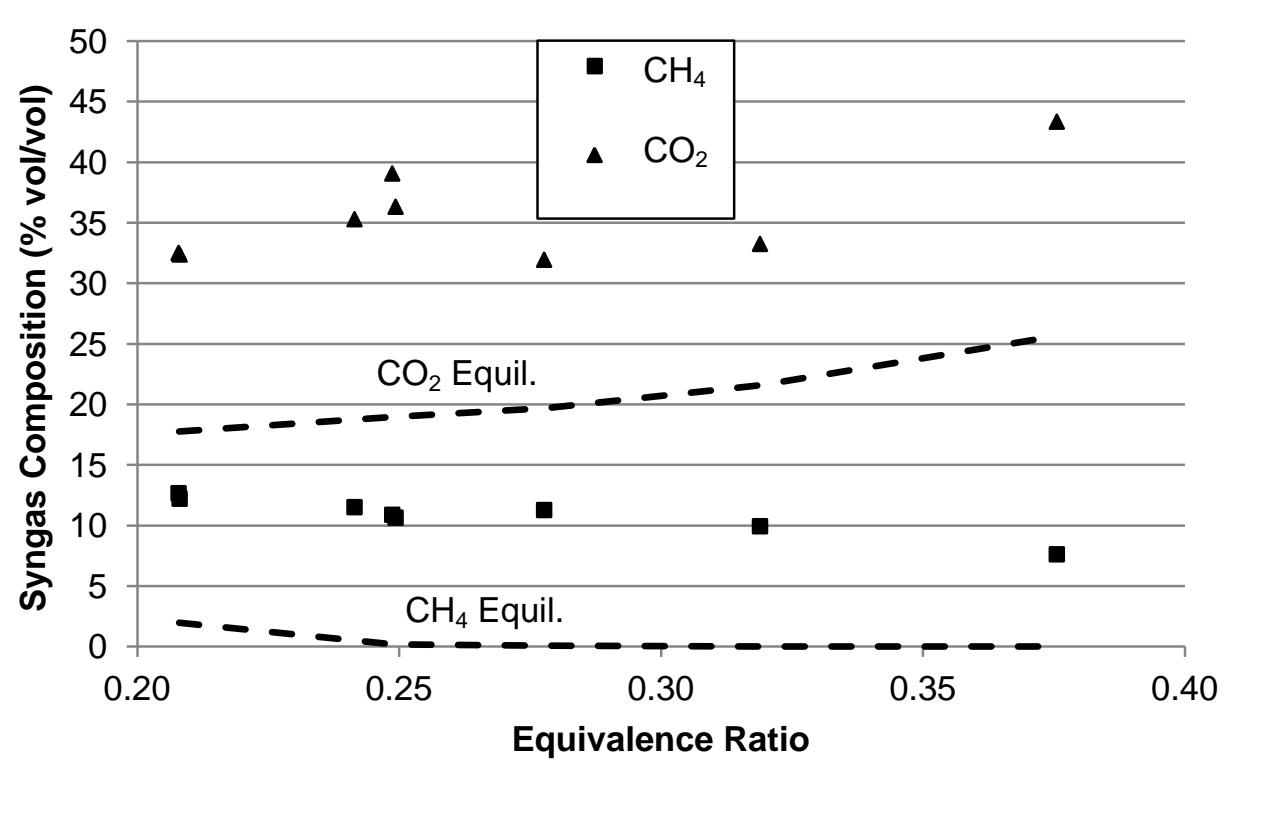

Figure

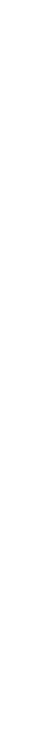

.

Equivalence Ratio

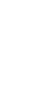

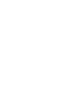

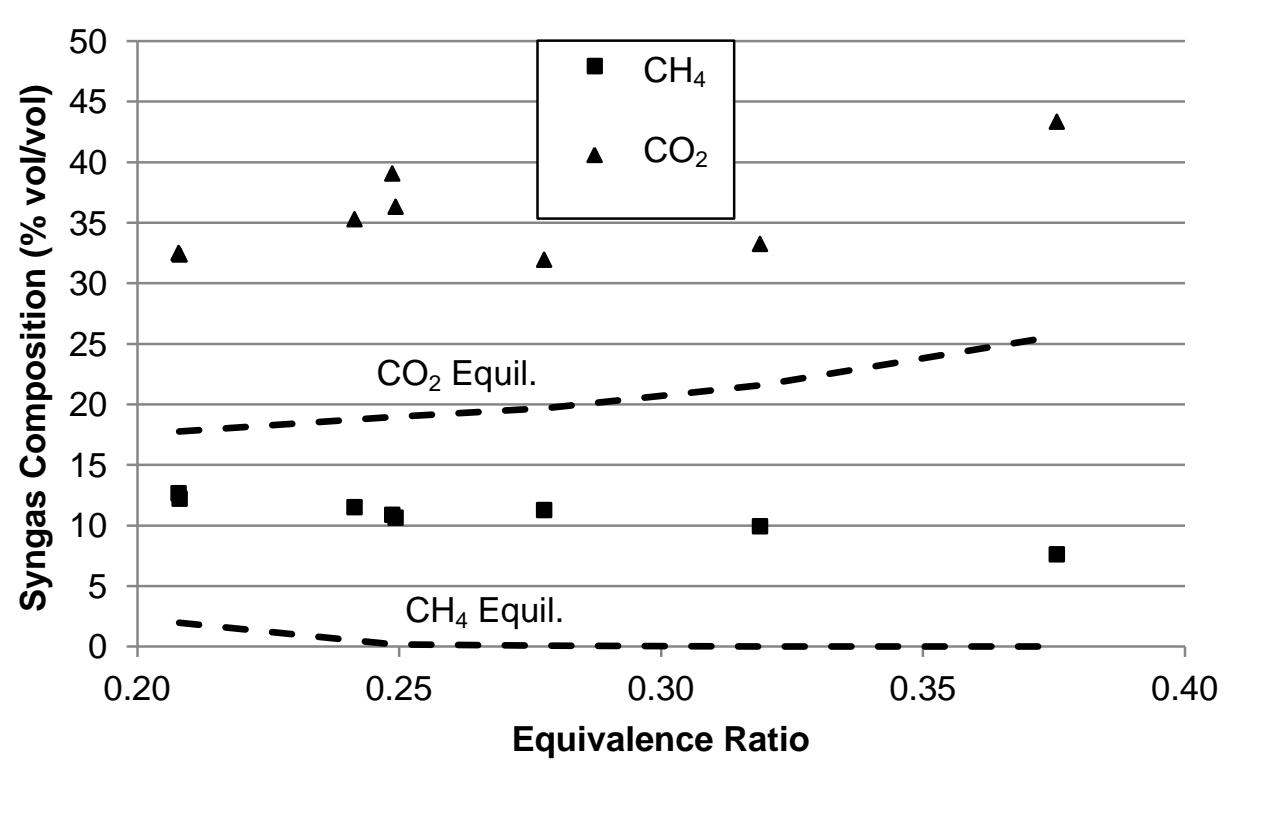

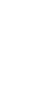




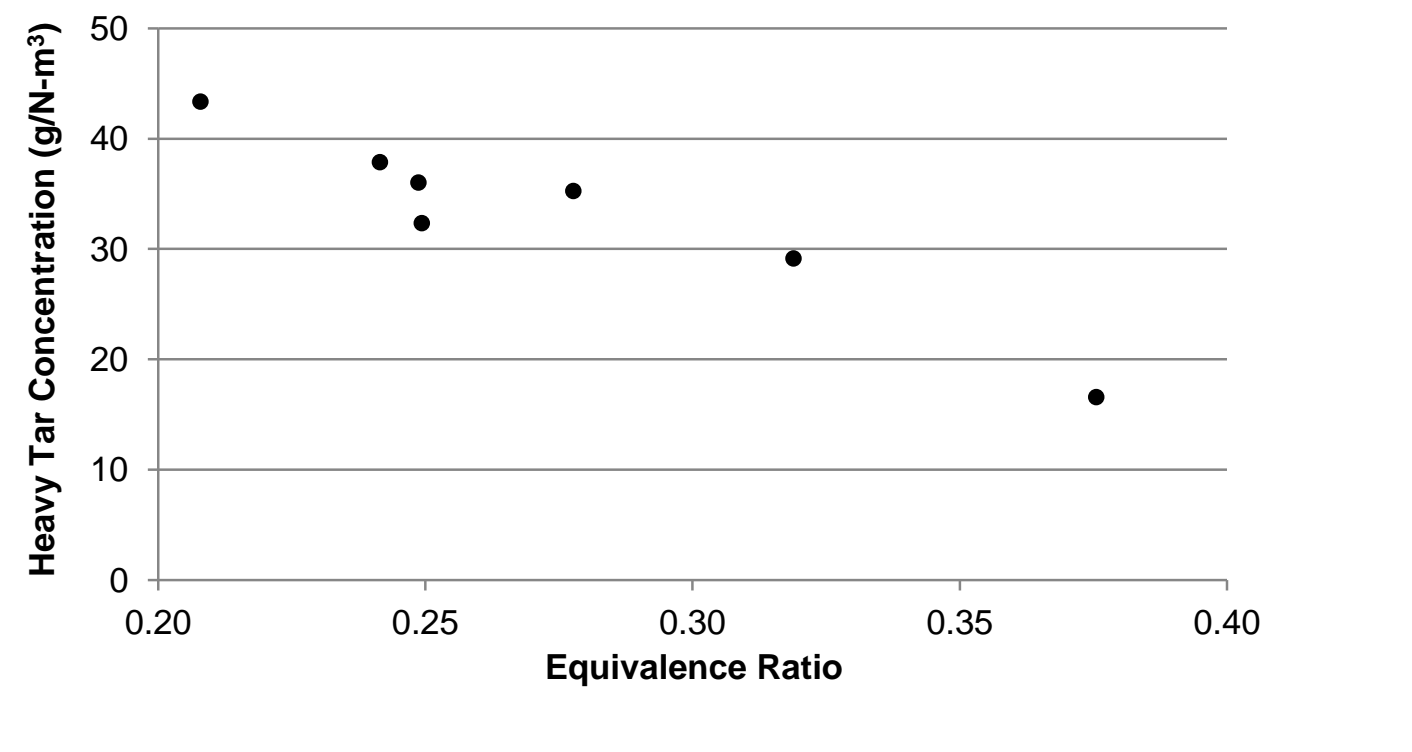

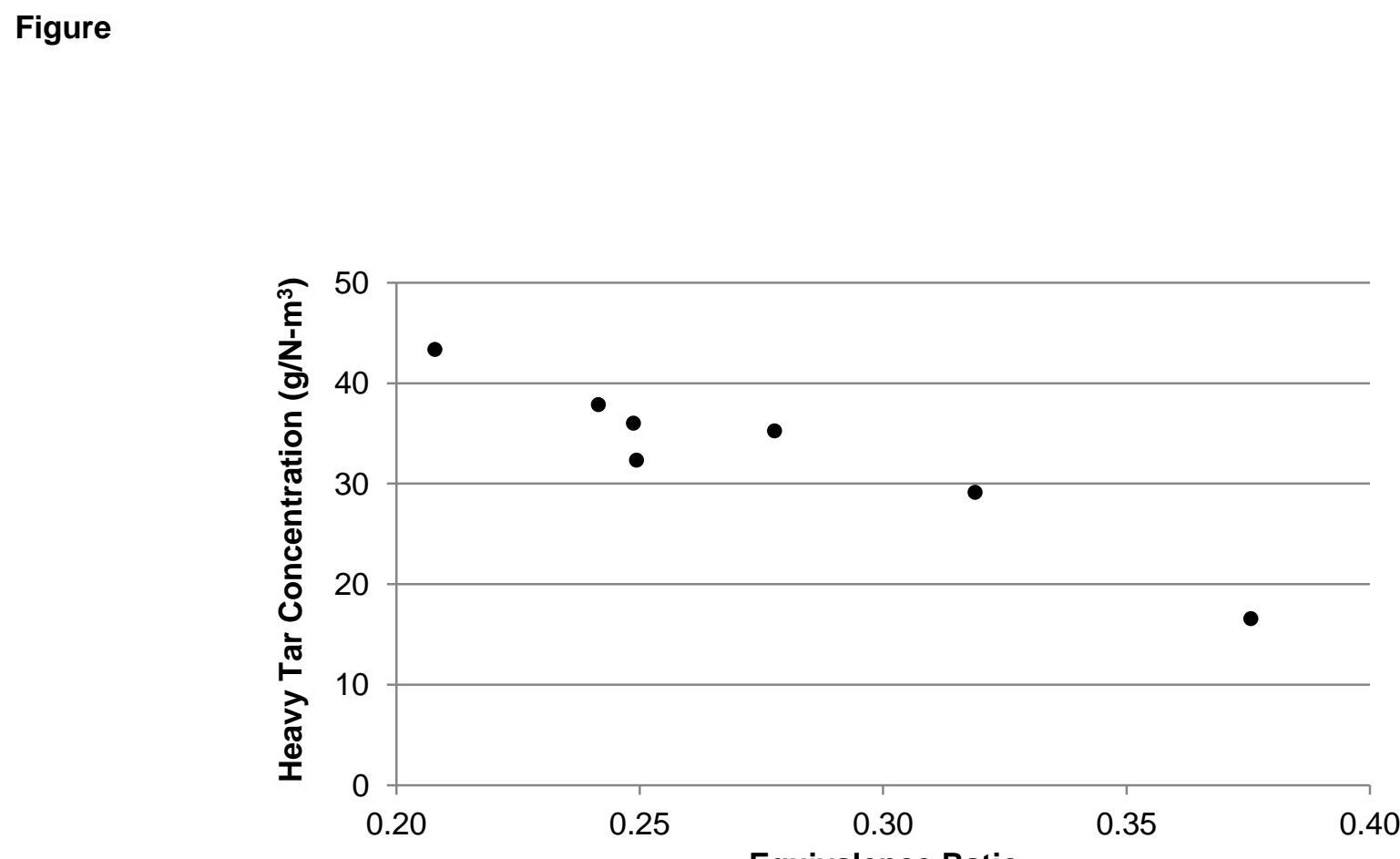

Equivalence Ratio

Equivalence Ratio 


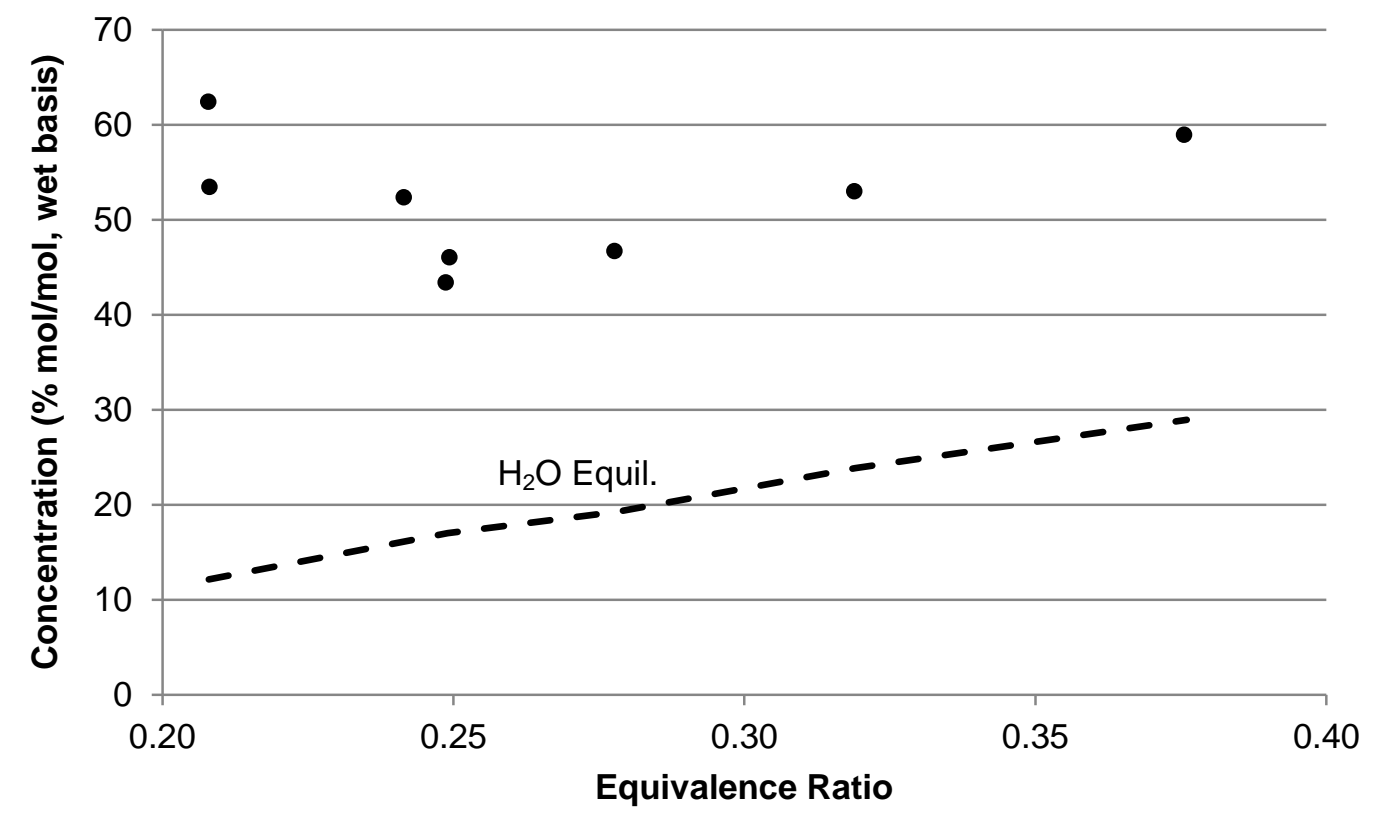

Figure

\section{Equivalence Ratio}

\section{Figure}

(a)

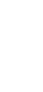
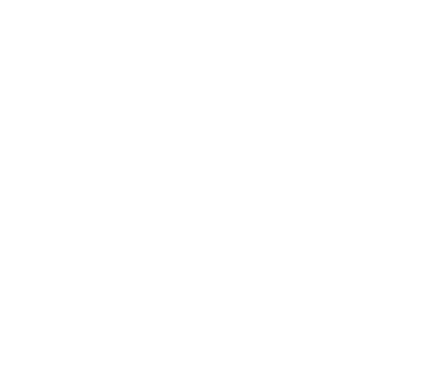


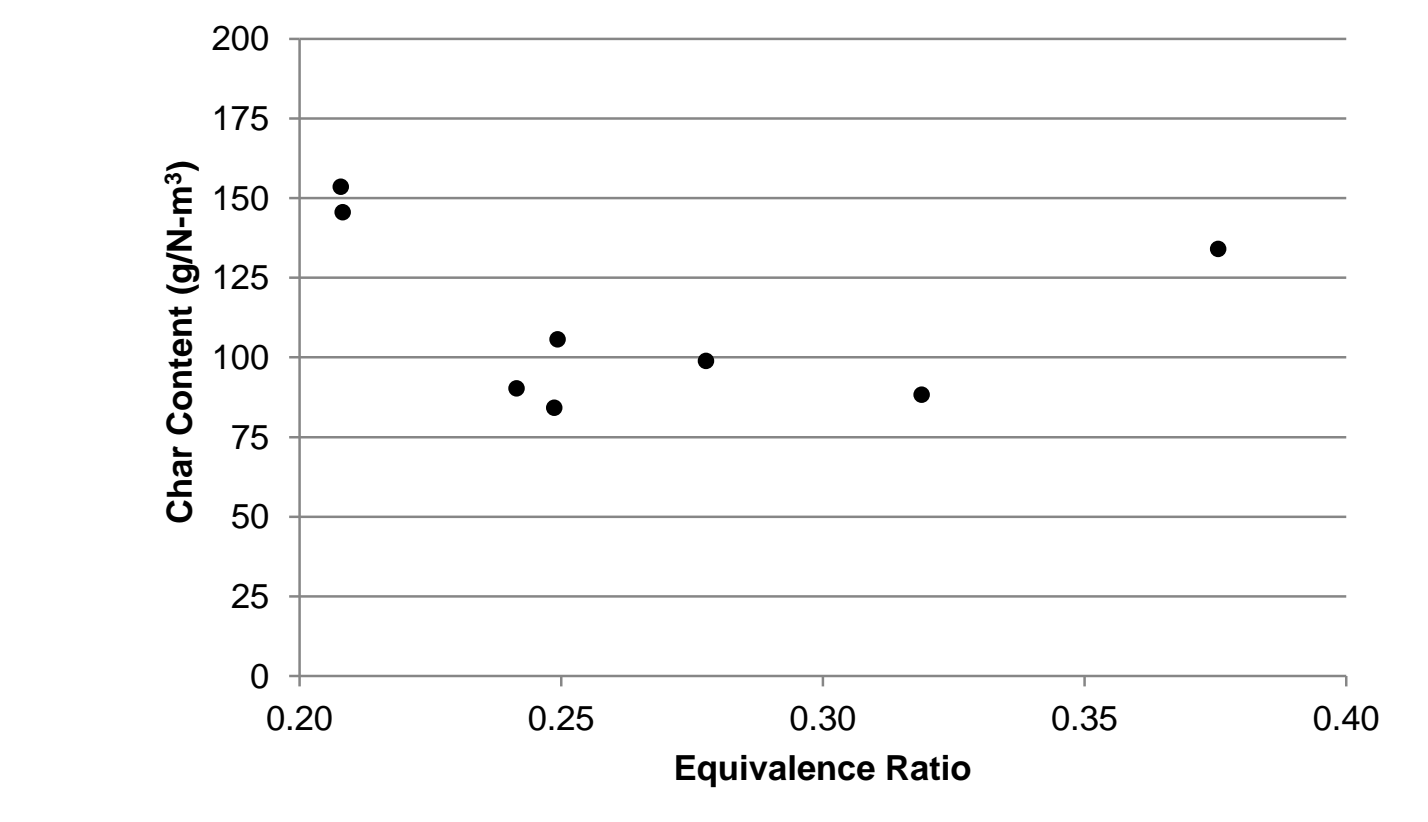

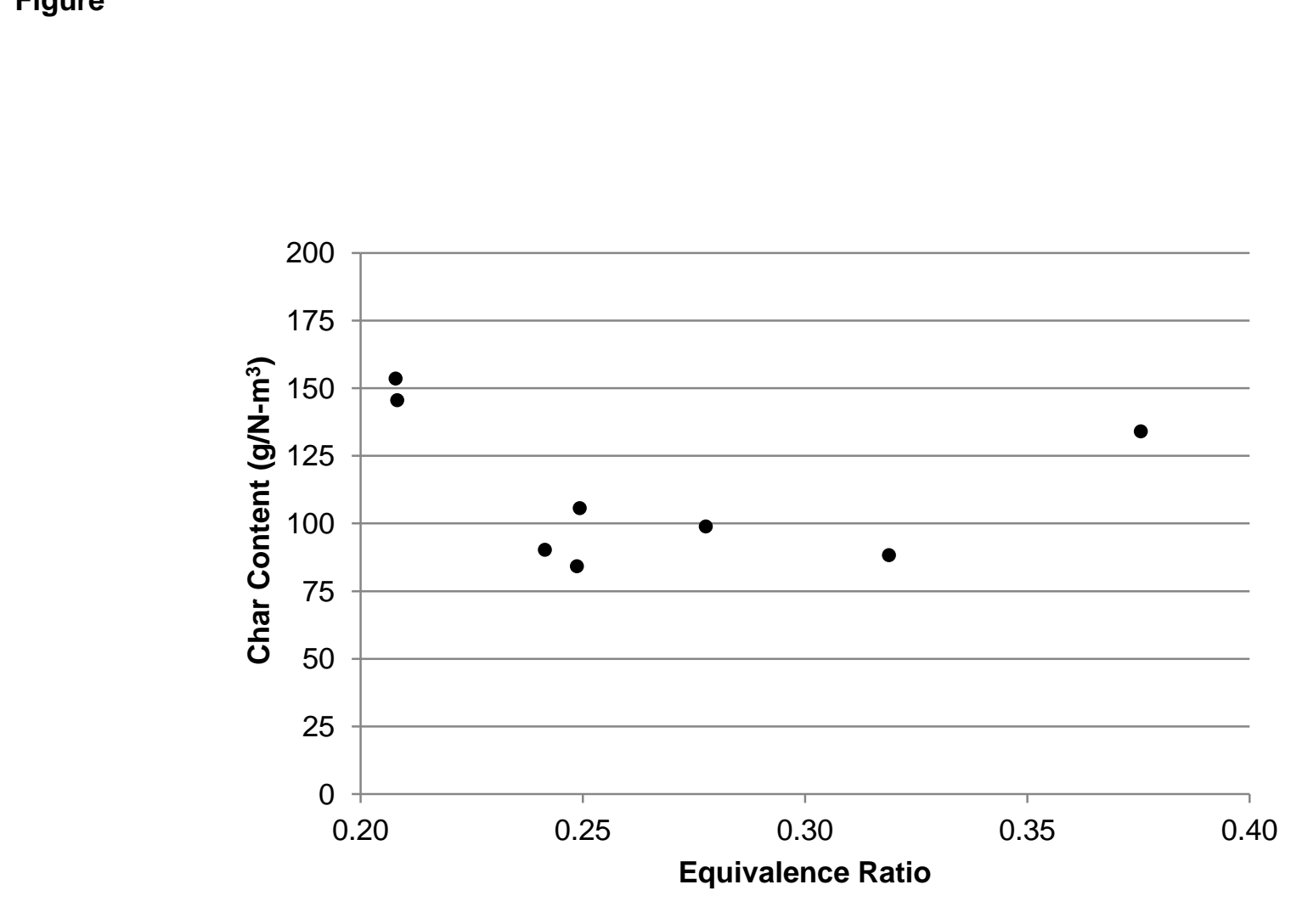

Figure

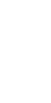

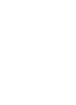

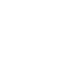

.

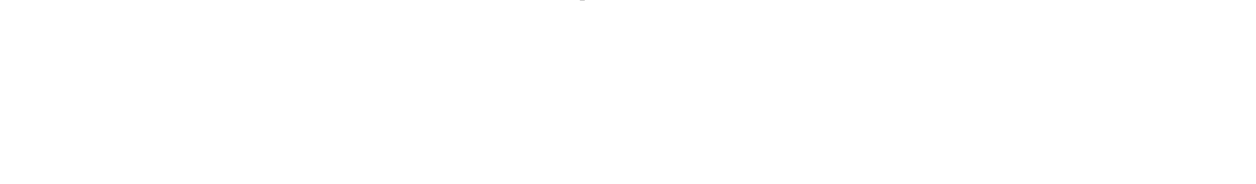



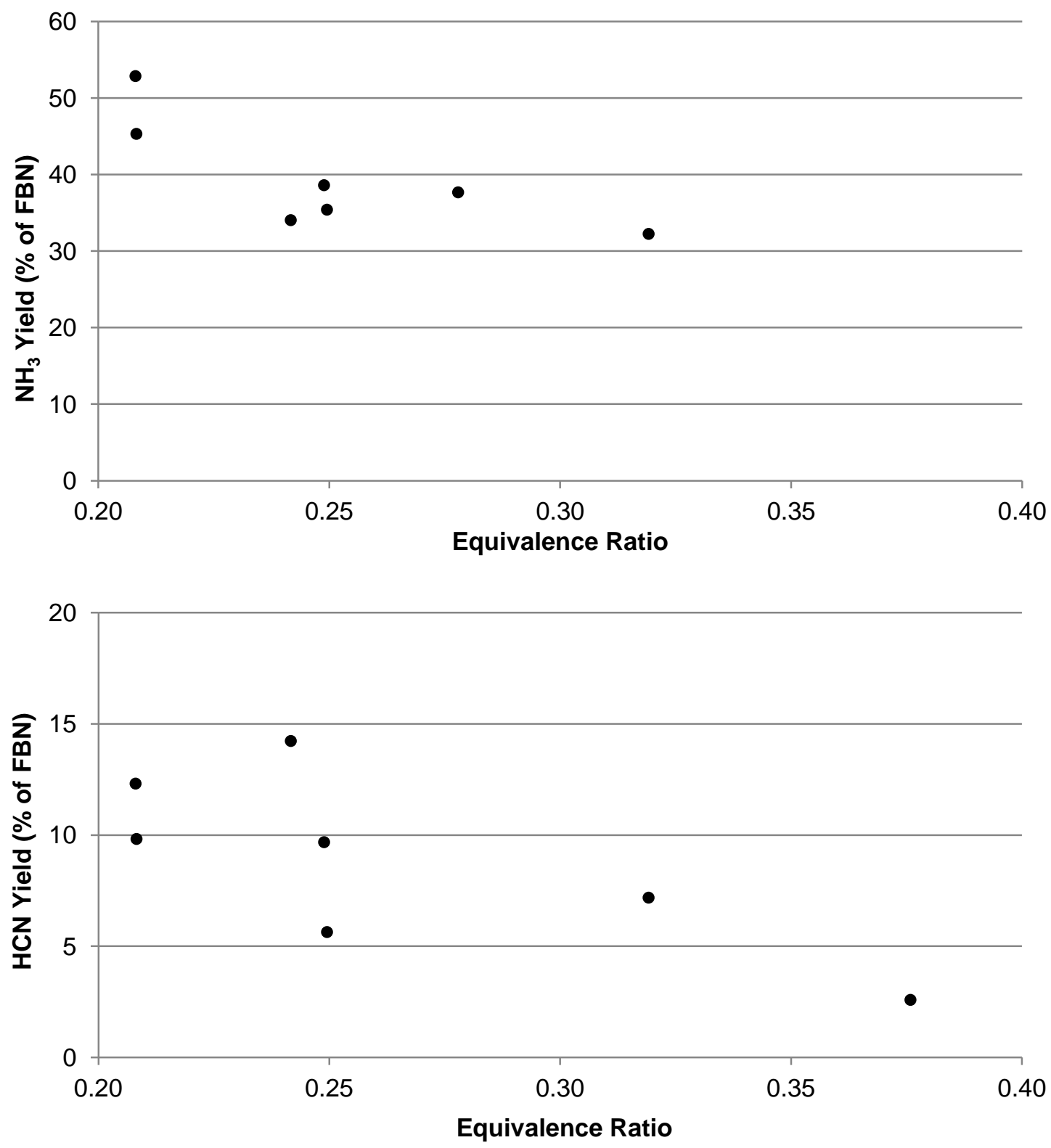